\title{
Antibodies against conserved antigens provide opportunities for reform in influenza vaccine design
}

\section{Denise A. Kaminski ${ }^{1}{ }^{*}$ and F. Eun-Hyung Lee ${ }^{2}$}

' Division of Allergy, Immunology, and Rheumatology, Department of Medicine, University of Rochester, Rochester, NY, USA

${ }^{2}$ Division of Pulmonary and Critical Care, Department of Medicine, University of Rochester, Rochester, NY, USA

\section{Edited by:}

George C. Tsokos, Harvard Medical

School, USA

\section{Reviewed by:}

Subbarao Bondada, University of Kentucky, USA

Rachel Gerstein, University of Massachusetts Medical School, USA

\section{*Correspondence:}

Denise A. Kaminski, Department of Medicine, University of Rochester, 601 Elmwood Avenue, Rochester, NY 14642, USA.

e-mail:denise_kaminski@urmc.

rochester.edu
High-performance neutralizing antibody against influenza virus typically recognizes the globular head region of its hemagglutinin (HA) envelope glycoprotein. To-date, approved human vaccination strategies have been designed to induce such antibodies as a sole means of preventing the consequences of this infection. However, frequent amino-acid changes in the HA globular head allow for efficient immune evasion. Consequently, vaccines inducing such neutralizing antibodies need to be annually re-designed and readministered at a great expense. These vaccines furthermore provide little-to-no immunity against antigenic-shift strains, which arise from complete replacement of HA or of neuraminidase genes, and pose pandemic risks. To address these issues, laboratory research has focused on inducing immunity effective against all strains, regardless of changes in the HA globular head. Despite prior dogma that such cross-protection needs to be induced by cellular immunity alone, several advances in recent years demonstrate that antibodies of other specificities are capable of cross-strain protection in mice. This review discusses the reactivity, induction, efficacy, and mechanisms of antibodies that react with poorly accessible epitopes in the HA stalk, with the matrix 2 membrane ion channel, and even with the internal nucleoprotein. These advances warrant further investigation of the inducibility and efficacy of such revolutionary antibody strategies in humans.

\section{Keywords: influenza virus, antibody, hemagglutinin, matrix 2 external domain, nucleoprotein, vaccine}

\section{INTRODUCTION}

Influenza virus epidemics are characterized by a 3 -day fever, respiratory affliction, and muscle pain affecting many individuals suddenly, a rise in elderly hospitalization and death, and widespread (pandemic) outbreaks at 10- to 50-year intervals (Potter, 2001; Gerdil, 2003; Taubenberger and Kash, 2010). These characteristic patterns allow estimation of influenza occurrences in the distant past (Potter, 2001; Gerdil, 2003). The term "influenza" is derived from the Italian word for "influence," based on its temporal association with, and initially presumed causality of astronomical patterns observed in winter skies, when flu outbreaks tend to occur (1989; Gerdil, 2003). This conclusion appeared reasonable only in the absence of alternative evidence. Despite more than 300 years of observation, identification of a causative agent, and even development of prevention strategies, influenza outbreaks still cost society billions of dollars in healthcare and lost productivity (Li and Leader, 2007; Molinari et al., 2007; Nichol et al., 2009; Nichol, 2011). To deal with this burden, influenza vaccination strategies have focused on inducing antibodies that neutralize virus by binding to the highly variable globular head domain of its hemagglutinin (HA) envelope spike (Tsuchiya et al., 2001; Tosh et al., 2010; Xu et al., 2010; Han and Marasco, 2011). However, efficient viral immune evasion driven by these antibodies necessitates costly re-formulation and re-administration efforts that struggle to keep pace with HA head antigenic changes (antigenic drift) and with replacement of HA in its entirety (antigenic-shift). This process has been repeated for decades with the presumed logic (to a degree, based on unawareness of alternative evidence) that classical neutralization is the only feasible means to prevent the consequences of this infection. However, a recent antigenicshift-induced influenza pandemic in the year 2009 (Fraser et al., 2009; Neumann et al., 2009) underscores the long-overdue need to implement alternative vaccination strategies that do not rely on antibody recognition of the variable HA globular head. Encouragingly, antibodies against other viral components have shown significant efficacy in animal models. Here, we discuss such antibodies and their implications for advancing human immunization strategies against influenza virus.

\section{SEASONAL HEMAGGLUTINATION-INHIBITING ANTIBODY}

$\mathrm{HA}$ is a transmembrane glycoprotein in the influenza virus lipid envelope (Skehel and Wiley, 2000; Rossman and Lamb, 2011). $\mathrm{HA}$ is composed of a membrane-distal globular head domain that mediates host-cell receptor binding, and a membraneproximal stalk domain that directs envelope fusion with the host-cell (Skehel and Wiley, 2000; Gamblin and Skehel, 2010; Figure 1). Anti-HA head antibodies can inhibit virus replication in true neutralization assays (inhibiting virion entry into host cells) in vitro, functioning both independently of additional host-derived effector molecules, but are also capable of cooperating with complement, depending on the antibody subclass (Mozdzanowska et al., 1999). In humans and experimental animals, pre-existing neutralizing antibody titers correlate with less febrile illness, fewer days of virus shedding, and lower viral titers 
A

\section{Influenza Hemagglutinin Trimer}

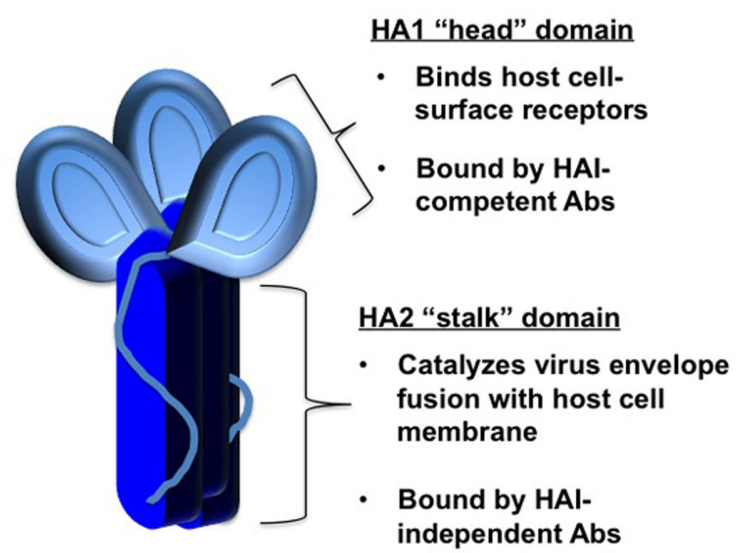

B

HA2 monomer, pH7

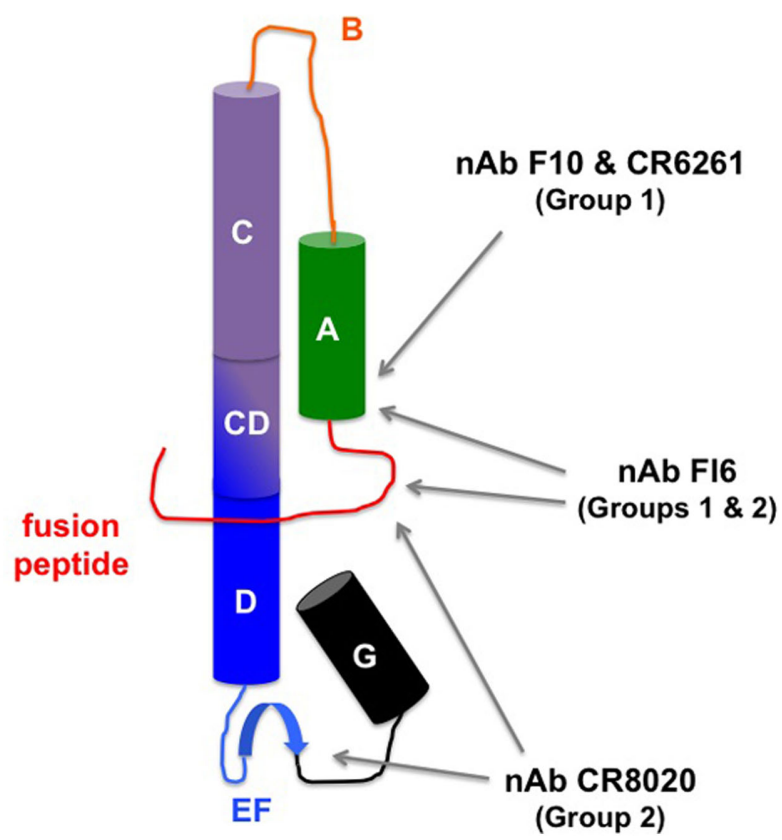

FIGURE 1 | Neutralizing antibody binding to hemagglutinin. (A) Gross structure of the hemagglutinin (HA). HA1 (light blue) makes-up most of the globular head domain as well as a polypeptide extension into the stalk area. HA2 (dark blue) makes-up the membrane-proximal stalk domain. (B) Schematized secondary structure of HA stalk monomer (HA2) in the pre-fusion conformation (adapted from Han and Marasco, 2011). Cylinders represent $\alpha$ helices and broad blue arrow represents a $\beta$ sheet. Middle red line represents $\mathrm{N}$-terminal fusion peptide. Previously defined subdomains are labeled with capital letters. Gray arrows point to epitope locations for the indicated broadly neutralizing antibody clones (nAb, see Table 1).

after infection (Murphy et al., 1972). The cause-and-effect relationship between anti-HA antibody and in vivo antiviral efficacy against matched strains is well-validated in laboratory animals both by active vaccination (Brett and Johansson, 2005; Nayak et al., 2010) and by passive transfer of antibody (Mozdzanowska et al., 1999; Yu et al., 2008). Functional activity of HA globular head-reactive antibodies can be approximated through their ability to inhibit virus-induced agglutination of vertebrate red blood cells in vitro - hence the term "hemagglutination inhibition" (HAI). Although "HAI" and "neutralizing antibody" have been frequently used interchangeably in the past, recent appreciation of virus-neutralizing antibodies lacking HAI activity (discussed below) are leading to more discriminate use of such terms. Additionally, multiple HAI-independent antibodies described in the sections below provide broader definitions of "protection" to include mechanisms other than preventing virion entry into host cells, because such antibodies nonetheless can reduce viral load and delay or prevent infection-induced death in experimental animals.

The receptor-binding site on the HA globular head is surrounded by protruding peptide loops. Anti-head antibodies against these loops sterically hinder receptor binding, and efficiently prevent host-cell attachment and virus entry, as depicted in Figure 2 (Skehel and Wiley, 2000; Han and Marasco, 2011). Thus, these classical, HAI-competent neutralizing antibodies are the condoms of the immune system, in that they provide an effective barrier method. Unfortunately, one size does not fit all. The HA head protruding loops are highly variable among virus strains, and the head-binding antibodies do not neutralize viruses that are not closely related to the immunogen (Yu et al., 2008; Hensley et al., 2009; Skountzou et al., 2010).

HA subtypes for influenza A are categorized based on a nomenclature that began with retrospective identification of the strain responsible for the 1918 influenza pandemic (H1N1, "Spanish Flu"), which killed 50 million humans world-wide (Basler and Aguilar, 2008; Taubenberger and Kash, 2010). Since this outbreak, the amino-acid globular head sequence of $\mathrm{H} 1$ circulating in humans significantly drifted from the $1918 \mathrm{H} 1$ sequence, while $\mathrm{H} 1$ concurrently circulated in swine with little divergence (Krause et al., 2010; Xu et al., 2010). After genetic reassortment with human and avian viral strains, swine $\mathrm{H} 1$ recently re-introduced itself into human circulation, causing a wide-spread, although less severe H1N1 pandemic in the year 2009 (Fraser et al., 2009; Itoh et al., 2009; Neumann et al., 2009; Smith et al., 2009). Whereas pre-2009 seasonal H1 human strain amino-acid sequences were only 50 $60 \%$ identical with $2009 \mathrm{H1}, 1918$, and $2009 \mathrm{H} 1$ were $80 \%$ identical to each other (Xu et al., 2010). This pattern likely explains a curious 2009 pandemic resistance among older adults previously exposed to the 1918 virus, correlating with long-lived cross-neutralizing antibodies in this cohort that is otherwise most susceptible to seasonal outbreaks (Yu et al., 2008; Fraser et al., 2009; Itoh et al., 2009; Xu et al., 2010; Xie et al., 2011).

As would be expected from the similarity between 1918 and 2009 H1 molecules, antibodies induced in humans before 1920 have HAI and neutralizing activity against $2009 \mathrm{H} 1 \mathrm{~N} 1$ pandemic virus (Hancock et al., 2009; Krause et al., 2010). At least some of these antibodies can also reduce lung viral titers when passively transferred into mice challenged with $2009 \mathrm{H} 1 \mathrm{~N} 1$ virus (Krause et al., 2010). However, such antibodies show little, if any, recognition of strains circulating in the decades more immediately 


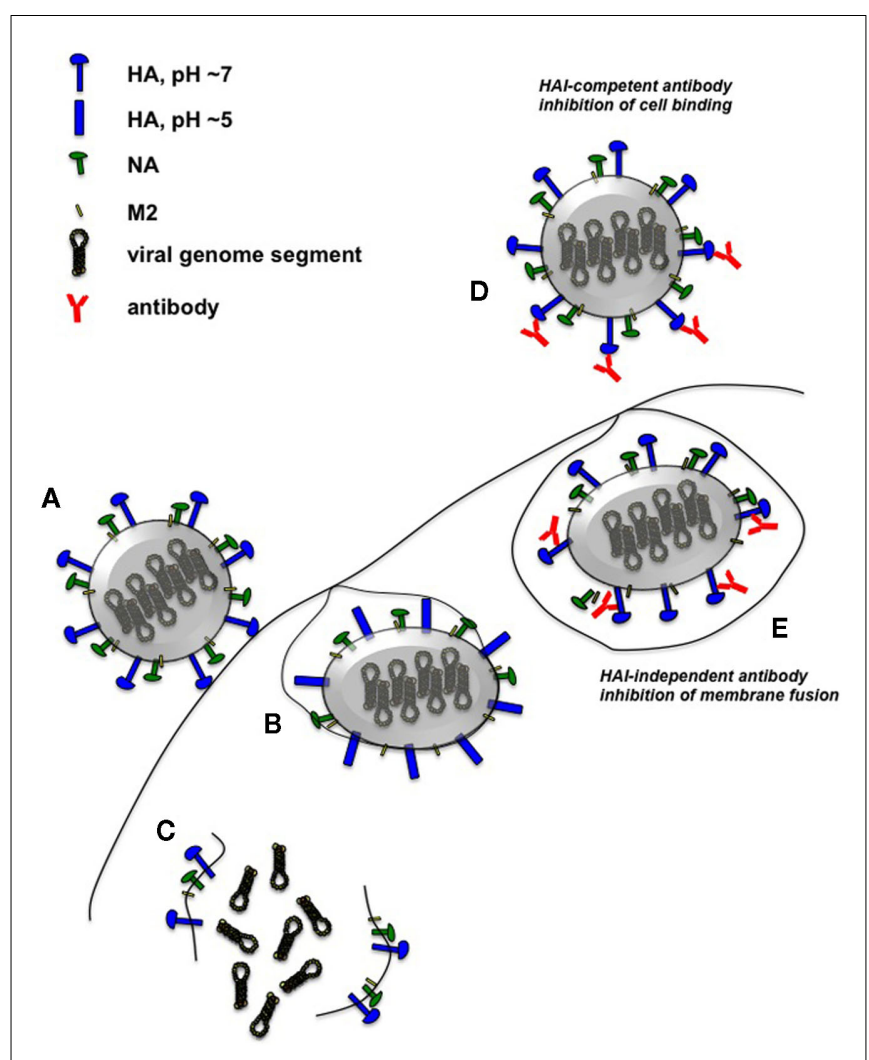

FIGURE 2 | Influenza virus infection and mechanisms of HA-specific neutralizing antibodies. Unimpeded influenza virus binds to receptors on the host-cell plasma membrane (A) and is internalized. The resulting vesicles become acidified via the $\mathrm{M} 2$ proton channel. This $\mathrm{pH}$ reduction results in $\mathrm{HA}$ conformational change that catalyzes the fusion of the host vesicle membrane with the viral envelope (B). The virion is subsequently dissociated into the cytoplasm (C), followed by transport of the ribonucleoprotein viral genome segments into the nucleus for replication and transcription (not shown). HAl-competent antibodies that bind to HA globular head effectively inhibit virion binding to host cells, preventing virus entry (D).

$\mathrm{HAl}$-independent neutralizing antibodies that react with the HA stalk region can prevent the conformational changes of this antigen and prevent fusion of viral envelope with host membrane (E). Not drawn to scale.

preceding the 2009 pandemic (Yu et al., 2008; Hancock et al., 2009). Priming mice by either sub-lethal infection or by vaccination with inactivated 1934 and $1957 \mathrm{H} 1 \mathrm{~N} 1$ strains can induce HAI against $2009 \mathrm{H} 1 \mathrm{N1}$, and vice versa (Skountzou et al., 2010). These reactivities correlate with cross-protection against lethality after challenge with live virus (Skountzou et al., 2010). However, priming mice with later (1983 and 1999) H1N1 strains is much less effective at inducing HAI against 2009 H1N1 (Skountzou et al., 2010). Therefore, the antigenic distance acquired over the seasons may contribute to waning cross-protection in humans, possibly explaining the unusually high incidence of the $2009 \mathrm{H} 1 \mathrm{~N} 1$ infection in younger individuals (Fraser et al., 2009). These observations indicate that although cross-protection with HAI-competent antibodies is possible, it is a continually moving target.

Among human, swine, and avian influenza virus reservoirs, 16 total HA subtypes have been identified that are clustered into two phylogenetic groups based on amino-acid sequence (Skehel and Wiley, 2000; Gamblin and Skehel, 2010; Han and Marasco, 2011; Medina and Garcia-Sastre, 2011). Phylogenetically, H1 clusters with $\mathrm{H} 2, \mathrm{H} 5, \mathrm{H} 6, \mathrm{H} 8$, and $\mathrm{H} 9$, whereas $\mathrm{H} 3$ clusters with $\mathrm{H} 4$ and H7 (Throsby et al., 2008; Sui et al., 2009; Han and Marasco, 2011; Medina and Garcia-Sastre, 2011). Between 1918 and 2009, two additional pandemics arose from genetic replacement of circulating $\mathrm{H} 1$ with $\mathrm{H} 2$ in 1957, and then replacement of $\mathrm{H} 2$ with H3 in 1968 (Basler and Aguilar, 2008; Taubenberger and Kash, 2010; Nabel et al., 2011). Since an accidental re-introduction of $\mathrm{H} 1 \mathrm{~N} 1$ virus in 1977, H1N1 and H3N2 viruses have co-circulated in humans, continuing to cause annual seasonal epidemics (2011). Unlike $\mathrm{H} 1$ and $\mathrm{H} 3$ viruses, $\mathrm{H} 5$-containing viruses are more common in birds than in humans. However, in 1997, the first of several sporadic and fatal (60\% mortality) human cases were reported in Asia (Basler and Aguilar, 2008; Korteweg and Gu, 2008). To-date, H5N1 transmission from human-to-human has been rare (Korteweg and $\mathrm{Gu}, 2008$ ). Yet, given the highly pathogenic nature of such viruses, a pandemic threat remains if even minor genetic changes in HA were to confer more efficient transmission among humans (Basler and Aguilar, 2008). A lack of existing herd immunity to $\mathrm{H} 5$ in humans coupled with the extreme virulence of such viruses predicts a pandemic of the severity more similar to that of the 1918 outbreak, rather than the more mild occurrence in 2009 (Basler and Aguilar, 2008). Rare cases of infection with H7N7 and H9N2 viruses have also been detected in humans, associated with agricultural exposure (Peiris et al., 1999; Koopmans et al., 2004; Taubenberger and Kash, 2010). Thus, continual HA drift in circulating human strains, emergence of new subtype sequences, and even re-emergence of archaic sequences from animal reservoirs, all of which may have little recognition by existing human immunity, provide a challenging task of seasonal vaccine matching as well as diverse opportunities for continued pandemic risks.

Current influenza vaccine strategies in humans, most commonly inactivated virus preparations, are designed to induce antiHA globular head antibodies (Mossad, 2007, 2008; Du et al., 2010; Tosh et al., 2010). Thus, HAI has been used as a measure of vaccine "take" and its presumed indication of "protection" (Whitley and Monto, 2006; Xie et al., 2011). Seroprotective levels of HAI are reported to be induced in $75-98 \%$ of individuals vaccinated, with an antiviral efficacy of 25-75\% (Ohmit et al., 2006; Nichol et al., 2007; Beran et al., 2009; Jackson et al., 2010; Xie et al., 2011). The accuracy of these latter values can be influenced by seasonal virus attack rates, study cohorts, degree of strain matching, and study endpoint criteria (Ohmit et al., 2006; Nichol et al., 2007; Jackson et al., 2010). Rise in circulating antibody-secreting cells (ASC) against the vaccine occurs within a week of immunization, concurrently with rise in HAI (which persists for weeks whereas ASC responses subsequently decline; Halliley et al., 2010). About $40 \%$ of the ASC against seasonal influenza vaccine are against HA, 20\% of which are HAI-competent (Wrammert et al., 2008). Given their relative specificity to the immunogen (Lee et al., 2011), these ASC responses are thus a very useful tool to measure vaccine immunogenicity without confounding effects of pre-existing antiviral serum antibody titers.

Because HA amino-acid sequences continue to drift (Han and Marasco, 2011), seasonal inactivated influenza vaccine is reformulated each year in an attempt to match the virus strains that 
are predicted to circulate (Gerdil, 2003; Mossad, 2007, 2008; Tosh et al., 2010). Because H1 and H3 influenza A viruses have been co-circulating together with influenza B since 1977, the current seasonal inactivated influenza vaccine consists of one $\mathrm{H} 1 \mathrm{~N} 1$ strain, one H3N2 strain, and one influenza B strain (Gerdil, 2003; Mossad, 2007, 2008; Tosh et al., 2010). This combination is referred to as the trivalent-inactivated vaccine, TIV. Because circulating H2N2 was replaced by H3N2 influenza in 1968, H2 strains are no longer included in annual vaccinations. Thus, HAI against $\mathrm{H} 2 \mathrm{~N} 2$ is highest in people between 61 and 70 years of age, and is very rare in people under 40 (as of 2011; Nabel et al., 2011). However, given the re-emergence of swine $\mathrm{H} 1 \mathrm{~N} 1$ as a de novo pandemic despite existing human $\mathrm{H} 1 \mathrm{~N} 1$ in circulation, concern has been raised that a similar re-emergence could occur with H2 (Nabel et al., 2011). Whether such a threat warrants preemptive H2N2 vaccinations is currently debated (Nabel et al., 2011). Such measures for any of the remaining HAs may have a high cost-to-benefit ratio, because they cannot be predicted with certainty.

In addition to limited cross-reactivity, HAI-competent antibodies are efficient at selecting escape mutants in vitro (Tsuchiya et al., 2001). Furthermore, serial passage of influenza virus in homologously vaccinated mice promotes the recovery of progeny viruses with mutated HA globular head sequences (Hensley et al., 2009). Such escape mutants are resistant to in vitro HAI and neutralization with polyclonal antibody, strongly correlating with increased host-cell binding capacity of the mutant viruses (Hensley et al., 2009). These mutant viruses are rapidly selected for in co-infections with the parental wild-type virus strain (Hensley et al., 2009). Therefore, despite the efficacy of anti-globular head antibodies, HAI-resistant viruses are efficiently selected by matched influenza vaccines and the antibodies that they induce.

\section{ANTIBODIES AGAINST HA STALK DOMAIN}

As discussed above, HAI-competent neutralizing antibodies are highly efficient at preventing and clearing influenza virus infection, but also provide a selective pressure for viral immune evasion. Thus, cross-protection against variant viral serotypes would require the immune system to recognize more conserved epitopes, which tend to be less accessible than the HA globular head. Such epitopes can be found in the membrane-proximal stalk region of HA (Han and Marasco, 2011; Figure 1B; Table 1). Anti-stalk antibodies lack HAI activity and do not inhibit virion binding to mammalian host cells, but nonetheless have neutralization activity in sensitive assays using HA-expressing pseudoviruses, and also passively protect mice from lethal challenge in vivo (Okuno et al., 1994; Throsby et al., 2008; Sui et al., 2009). Structural modeling suggests that these antibodies bind a hydrophobic patch in the stalk region helical bundle of the protein's tertiary structure (Throsby et al., 2008; Ekiert et al., 2009; Sui et al., 2009). Binding of cell surface HA by anti-stalk antibodies is sensitive to low $\mathrm{pH}$ and to reducing agents (Throsby et al., 2008), indicating conformation-sensitive recognition of the molecule. Anti-stalk antibody binding does not change HA trimer structure, and actually prevents $\mathrm{pH}$-induced "post-fusion-like" conformation change (Ekiert et al., 2009). These observations suggest that the antiviral mechanism of anti-stalk antibodies involves inducing conformational changes that interfere with HA-mediated virus-host-cell fusion (Figure 2). This suggestion is supported by a cell culturebased syncytia-forming assay (Sui et al., 2009). However, a recently described anti-HA stalk antibody has been shown to have reduced in vivo efficacy if the constant region is mutated to eliminate complement binding, and is nearly (but not completely) eliminated if it cannot bind Fc receptors (Corti et al., 2011). To what degree these different mechanisms are responsible for the in vivo antiviral activity of different clones of these antibodies remains to be determined. Understanding these mechanisms will be useful in determining what antibody effector subclasses will be most useful to engineer for passively transferred antibodies and to induce with selected adjuvants in human vaccinations. Comparable in vivo efficacy and in vitro function have also been described for a monoclonal antibody recognizing a conserved epitope in the underside of the HA globular head (Oh et al., 2010).

As would be expected from antigenic sequence conservation, anti-stalk antibodies initially generated against $\mathrm{H} 5$ react with and show in vitro activity against other phylogenetic group 1 HAs,

Table 1 | HA stalk-reactive antibodies that have been structurally analyzed.

\begin{tabular}{|c|c|c|c|c|c|c|c|}
\hline Ab clone & Source & Strain reactivity & Epitope location* & Ab chains used & $V$ genes & HCDRs used & Reference \\
\hline $\mathrm{Fl6}$ & $\begin{array}{l}\text { Sequence-optimized from } \\
\text { human plasma cell cultures }\end{array}$ & $\begin{array}{l}\text { Both group } 1 \text { and } \\
\text { group } 2\end{array}$ & $\begin{array}{l}\text { Fusion peptide and } \\
\text { A helix** }\end{array}$ & Both $\mathrm{HC}$ and $\mathrm{LC}$ & $\begin{array}{l}\text { VH3-30, } \\
\text { Vк4-1 }\end{array}$ & 3 only & Corti et al. (2011) \\
\hline CR6261 & $\begin{array}{l}\text { Human IgM } \\
\text { memory-phenotype B cell } \\
\text { phage-display library } \\
\text { selected with H5 }\end{array}$ & Group 1 only & A helix & Only HC & VH1-69 & 1,2 , and 3 & $\begin{array}{l}\text { Ekiert et al. (2009), } \\
\text { Throsby et al. (2008) }\end{array}$ \\
\hline CR8020 & $\begin{array}{l}\text { Immortalized human } \\
\text { memory-phenotype B cells } \\
\text { selected with fluorescently } \\
\text { labeled H3 }\end{array}$ & Group 2 only & $\begin{array}{l}\text { Base } \beta \text { sheet and } \\
\text { fusion peptide }\end{array}$ & Both $\mathrm{HC}$ and $\mathrm{LC}$ & $\begin{array}{l}\text { VH1-18, } \\
\text { Vк3-20 }\end{array}$ & 1,2 , and 3 & Ekiert et al. (2011) \\
\hline
\end{tabular}

* See Figure 1B. ${ }^{* *}$ FI6 and F10 cross-compete.

$A b$, antibody; HC, antibody heavy chain; $L C$, antibody light chain; HCDRs, complementary-determining regions of the antibody heavy chain. 
including H1, H2, H6, H8, and H9 (Throsby et al., 2008; Ekiert et al., 2009; Sui et al., 2009; Corti et al., 2010; Steel et al., 2010; Wei et al., 2010). However, such cross-reactivity is typically limited to group $1 \mathrm{HAs}$, as these antibodies poorly react or function against the group 2 proteins $\mathrm{H} 3$, H4, or H7 (Throsby et al., 2008; Ekiert et al., 2009; Sui et al., 2009; Corti et al., 2010; Steel et al., 2010; Wei et al., 2010). Similarly, anti-stalk antibodies injected in vivo generated against $\mathrm{H} 5$ trimers protect mice from lethal doses of group 1, but not group 2 viruses (Okuno et al., 1994; Throsby et al., 2008; Sui et al., 2009; Wrammert et al., 2011). Reciprocally, another antibody clone has been described that can function effectively against group 2, but not group 1 viruses (Ekiert et al., 2011). The antigroup 2 antibody binds the HA stalk closer to the viral envelope compared with the epitope bound by group 1-reactive antibodies (Figure 1B; Table 1; Ekiert et al., 2011). Additional clones have been identified that can effectively function against both group 1 and group 2 viruses (Corti et al., 2011). Some intriguing differences between the pan-reactive clones and the group-restricted clones include the derivation of the latter from $\mathrm{CD}_{13} 8^{+}$plasma cells as opposed to IgM memory-phenotype B cell sequences, as well as a more restricted use of complementary-determining region (Table 1). These differences possibly suggest distinct induction pathways of pan-specific and group-specific responses. The costbenefit relationship of determining how to confidently induce one pan-specific response with monovalent vaccination versus developing bivalent vaccines to induce a combined response to Group 1 and Group 2 viruses remains to be determined.

The characterization of stalk-reactive antibodies is a promising advance for improving cross-protective human vaccine development. To fully take advantage of this benefit, it is important to understand how such antibodies can be induced. Interestingly, cross-reactive anti-HA stalk monoclonal antibodies have been generated from the acute response to $2009 \mathrm{H} 1 \mathrm{~N} 1$ pandemic virus and also from healthy subjects vaccinated with inactivated virus (Corti et al., 2010, 2011; Sui et al., 2011; Wrammert et al., 2011). Whereas these approaches used cell and molecular biology techniques to isolate and express these antibody specificities, it is unknown how to induce high-titer anti-HA stalk antibody in humans. Anti-HA stalk antibodies can be induced in mice by priming with HA-encoding DNA followed by seasonal TIV boost (Wei et al., 2010). This strategy has the advantage of using material (TIV) already approved for human use. Anti-HA stalk antibody can also be induced by immunizing mice with virus-like particles containing a "headless" HA protein lacking the globular domain (Steel et al., 2010). In both of these approaches, protection by active immunization and by passive serum transfer is restricted to viruses whose HAs are in the same phylogenetic group as that of the immunogen (Steel et al., 2010; Wei et al., 2010). However, if mice are instead vaccinated with a construct of only the long $\alpha$ helix of the $\mathrm{H} 3$ stalk (strain $\mathrm{A} / \mathrm{HK} / 68 \mathrm{HA}$ amino acids $76-130$ fused with the carrier protein, keyhole limpet hemocyanin), improved mouse survival and reduced viral load is observed for both group 2 and for some group 1 viruses (Wang et al., 2010). Although this protection is less robust in the opposite group, this result indicates that a more cross-protective epitope(s) is contained within the long $\alpha$ helix that is/are immunogenically obscured by the remainder of the stalk domain. This critical finding will likely help advance development of human vaccines to induce such antibodies.
Despite the promising cross-protective potential demonstrated for anti-HA stalk antibodies, such antibody can select virus escape mutants in vitro after several passages (Tsuchiya et al., 2001; Throsby et al., 2008). Such viral escape mutants are characterized by replacements of lysine 40 to either arginine or glutamine, as well as threonine 273 replaced with lysine (Tsuchiya et al., 2001). However, HAI-competent neutralizing antibody selects mutant viruses at a higher rate than non-HAI neutralizing antibody when compared side-by-side (Tsuchiya et al., 2001). Thus, at least in the shorter term, anti-stalk antibodies are more cross-protective with less potential for promoting immune evasion compared with HAI-competent antibodies. These observations strongly suggest that advances in vaccine development would benefit from shifting focus from HAI-dependent to HAI-independent antibody induction. Notably, homosubtypic-immune serum in which HAI antibodies predominate, can transfer immune protection from death in as little as $10 \mu \mathrm{l}$ per recipient mouse (Brown et al., 2006), whereas the anti-stalk-immune serum has been tested at $200 \mu \mathrm{l}$ (Wang et al., 2010). Careful side-by-side comparisons of purified antibody will need to be performed to determine whether or not anti-HA stalk antibodies have particular quantitative advantages over those against highly conserved proteins, discussed in subsequent sections.

\section{ANTIBODY AGAINST NEURAMINIDASE}

Neuraminidase (NA) is the second major influenza transmembrane glycoprotein, which exists as a homotetramer in the viral envelope (Gamblin and Skehel, 2010). NA cleaves sialic acid from the surface of infected cells and from newly formed viruses, allowing new virus release while preventing virion aggregation (Gamblin and Skehel, 2010). In vitro, anti-NA antibody does not neutralize virus (prevent host-cell entry), but instead prevents viral plaques from enlarging (Mozdzanowska et al., 1999). Thus, antibody-mediated inhibition of NA enzymatic activity may function to prevent new virion release (Figure 3). NA-inhibiting serum titers correlate with lower incidence of influenza-induced febrile illness, fewer days of virus shedding, and lower viral titers in humans (Murphy et al., 1972). Although NA-reactive antibody can be induced in humans after TIV immunization, this induction is reported to occur in fewer individuals than those that experience HAI induction with the same vaccine (Powers et al., 1996). Swine vaccination with inactivated virus has also failed to induce NA reactivity (Kim et al., 2006). Immunization of laboratory animals with NA protein or DNA induces NA-inhibiting antibody titers that correlate with reduced viral load, although such immunization can be less effective than HA immunization (Johansson and Kilbourne, 1993; Johansson et al., 1998; Brett and Johansson, 2005; Nayak et al., 2010). Similarly, passive transfer of anti-NA monoclonal antibody into mice can reduce viral load upon challenge infection, but the clones tested thus far appear to be less effective than anti-HA or anti-M2 (matrix 2) antibody (discussed below; Treanor et al., 1990; Mozdzanowska et al., 1999; Sandbulte et al., 2007). Reports differ on how well NA vaccination can cross-protect laboratory animals against NA-heterologous virus of the same subtype as the vaccine (Johansson et al., 1998; Brett and Johansson, 2005; Sandbulte et al., 2007). However, whole virus vaccination of mice does not induce in vivo selection of NA mutants, as is the case for HA (Hensley et al., 2009). Nonetheless, in the context of 


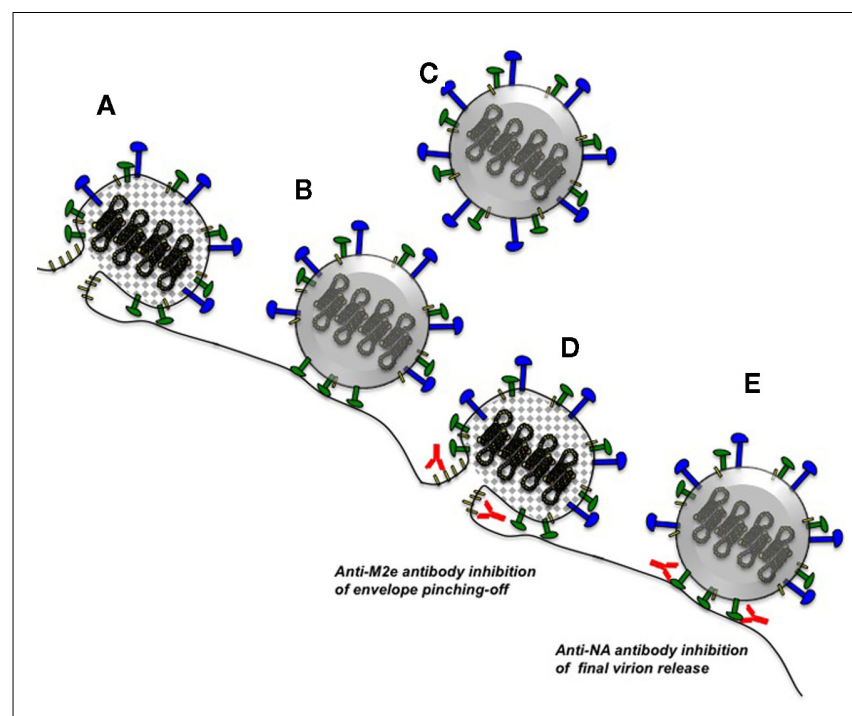

FIGURE 3 | Influenza virus release and possible mechanisms for antibodies against NA and M2e. Infected host cells package eight ribonucleoprotein genome segments into viral buds formed by $\mathrm{M} 1$ capsid monomers (gray diamonds) and host plasma membrane containing $\mathrm{HA}$, NA, and M2 (A). M2 catalyzes membrane fusion to pinch-off newly budded virions, which initially remain tethered to sialic acid on the host-cell surface (B). NA enzymatic activity cleaves the interactions of tethered HA (not depicted) and NA with sialic acid, effectively releasing the new virions (C). Antibodies against M2e may interfere with the pinching-off stage of viral budding (D), whereas antibodies against NA may prevent final release of the virion (E). See Figure 2 for symbol legend. Not drawn to scale.

other options for antibody reactivities against influenza virus, the relative efficacy and immunogenicity of anti-NA antibody have prompted little sustained interest by vaccinologists.

\section{FUNCTIONAL NON-NEUTRALIZING ANTIBODIES AGAINST CONSERVED ANTIGENS \\ MATRIX 2 EXTERNAL DOMAIN}

Matrix 2 (M2) is a third transmembrane protein expressed in the influenza A virus envelope (Lamb et al., 1985; Jegerlehner et al., 2004; Gabbard et al., 2009; De Filette et al., 2011; Rossman and Lamb, 2011). M2 homotetramers form a proton channel that participates in virus budding by orchestrating membrane pinching-off into enveloped virions (Rossman and Lamb, 2011). In vitro, anti-M2 antibodies prevent virus release into culture supernatant and also reduce viral plaque size without affecting plaque number (Mozdzanowska et al., 1999; Gabbard et al., 2009; Nayak et al., 2010). Thus, like anti-NA antibodies, anti-M2 antibodies may restrict viral propagation by preventing new virion release (Figure 3). In vivo, anti-M2 antibody can reduce mouse lung viral load and rescue survival after virus challenge (Treanor et al., 1990; Mozdzanowska et al., 1999; Jegerlehner et al., 2004; Ernst et al., 2006; Tompkins et al., 2007; El Bakkouri et al., 2011). This protective effect does not require lymphocytes to function downstream of the antibody (Jegerlehner et al., 2004; Zharikova et al., 2005), but does require activating Fc receptors as well as clodronate-sensitive cells (El Bakkouri et al., 2011), suggesting macrophage involvement in the antiviral mechanism. In fact, Fc receptor expression on alveolar macrophages is sufficient to mediate anti-M2 antibody-mediated protection (El Bakkouri et al., 2011). Thus, whether the mechanism suggested by in vitro data in the absence of macrophages (Figure 3) is simply not responsible for in vivo efficacy or requires cooperation with Fc receptors is unknown.

In mice, respiratory infection with live influenza A virus (Feng et al., 2006; Rangel-Moreno et al., 2008) or vaccination with inactivated virus (Jegerlehner et al., 2004) induces little, if any, anti-M2 serum antibody. Such poor responses may result from the poorly exposed external domain (M2e), which is only 23 amino acids on the virus' exterior. Nonetheless, protective titers of anti-M2e antibody correlating with reduced viral load and improved postinfection survival can be induced by immunizing animals with plasmid and viral vectors encoding M2 (Epstein et al., 2000, 2005; Tompkins et al., 2007; Lo et al., 2008; Misplon et al., 2010; Nayak et al., 2010) or by immunizing with M2e peptide expressed as a chimeric molecule with larger proteins (Neirynck et al., 1999; Jegerlehner et al., 2004; Ernst et al., 2006; De Filette et al., 2011). Such protein fusions are poorly immunogenic and poorly effective if only the N-terminal nine amino acids of M2e are used (De Filette et al., 2011), indicating that the protective epitopes are between amino acids 10 and 23, corresponding to the sequence proximal to the viral membrane when in situ. The immunogenicity and efficacy of M2 immunization in mice has been linked to host genetic factors, including major histocompatibility loci (Misplon et al., 2010). Thus, careful consideration needs to be given to how specific T cell help for M2e-specific antibodies could be induced among genetically diverse human individuals.

At the amino-acid level, M2e is $\sim 90 \%$ identical among influenza A strains (Gabbard et al., 2009). This conservation is likely why M2e vaccination or passive transfer of M2e-immune antibody can protect mice from various strains of influenza (Neirynck et al., 1999; Ernst et al., 2006; Tompkins et al., 2007). However, a position-10 amino-acid difference between human (proline) and avian (leucine) strains can prevent cross-protection with the same antibodies (Tompkins et al., 2007). Additionally, antibody-resistant mutants can be selected in vitro, which are then resistant to the antiviral effects of these antibodies in vivo (Zharikova et al., 2005). Such M2e-escape mutants tend to have a proline-10 change to either histidine or leucine (Zharikova et al., 2005; Gabbard et al., 2009). Thus, like anti-stalk antibodies, antiM2e antibodies are more cross-reactive and cross-protective than anti-head HAI-competent antibodies, but are nonetheless not completely universal.

\section{NUCLEOPROTEIN}

Influenza nucleoprotein (NP) is a histone-like polypeptide that forms the chromatin structure of the virus' RNA genome (Portela and Digard, 2002; Hutchinson et al., 2010). In infected host cells, NP also participates in viral RNA synthesis and ribonucleoprotein complex nuclear translocation (Portela and Digard, 2002; Hutchinson et al., 2010). It is thus not immediately apparent that antibody against such a protein would be able to find its cognate antigen during an infection in order to stimulate putative antiviral reactions, the nature of which, would be even less obvious. However, as early as 2 days after mouse infection with influenza virus, 
cell-free NP protein is readily detectable in the airways (LaMere et al., 2011a). Whether such release of this protein is associated with death of infected cells or some other mechanism linked to the virus replication cycle is unknown. Similarly, the role, if any, of plasma membrane-associated NP detected on cultured cells (Virelizier et al., 1977; Yewdell et al., 1981) in virus replication is also unknown.

NP antigen has long been an attractive candidate for a universal influenza vaccine, due to its extensive conservation among influenza A strains (Shu et al., 1993; Portela and Digard, 2002). In fact, NP immunization promotes viral clearance and prevents mortality in mice after challenge with various viral serotypes (Wraith et al., 1987; Ulmer et al., 1993, 1998; Fu et al., 1999; Epstein et al., 2000, 2005). NP-immune protection correlates with the induction of NP-specific CD8 T cell responses (Wraith et al., 1987; Ulmer et al., 1993, 1998; Fu et al., 1999; Epstein et al., 2000, 2005; Lo et al., 2008), and T cell depletion can abrogate NP-immune protection (Ulmer et al., 1998; Epstein et al., 2000). This evidence was initially interpreted to mean that NP-immune protection in a universal human vaccine should be solely based on inducing the appropriate $\mathrm{T}$ lymphocyte responses, and that anti-NP antibody would have little, if any, role in this process. Nonetheless, NP-immune antibody can promote virus clearance and survival in mice (Carragher et al., 2008; LaMere et al., 2011a,b), and may explain the need for B cells and antibody in subtype cross-protection induced by previous infection with $\mathrm{HN}$ disparate strains (heterosubtypic immunity; Nguyen et al., 2007; Rangel-Moreno et al., 2008; LaMere et al., 2011a).

Compared with antibodies against virion envelope proteins, the antiviral mechanisms of anti-NP antibody are much less apparent. As expected, anti-NP antibody does not neutralize virus or substantially change viral plaques in vitro (Mozdzanowska et al., 1999; Gabbard et al., 2009). However, cross-protective influenzaimmune non-neutralizing antibody can cooperate with cultured macrophages to inhibit virus replication (Sambhara et al., 2001), although it is unclear if this effect is due to anti-NP antibody. Cultured influenza-infected cells with NP exposed on the plasma membrane can be lysed by complement in the presence of anti-NP antibody (Yewdell et al., 1981). Whether complement or other non-neutralizing mechanisms such as antibodydependent cell-mediated cytotoxicity (Ahmad et al., 2001; Forthal et al., 2001; Gomez-Roman et al., 2005; Hessell et al., 2007) or antibody-mediated cytokine induction (Palmer et al., 2000; Chehadeh et al., 2001; Hober et al., 2001; Stratov et al., 2008) contribute to the in vivo activity of anti-NP antibody is unknown. At least some of the in vivo antiviral activity of this antibody against lethal, but not sub-lethal influenza infection has been attributed to type I interferon receptor signaling (LaMere et al., 2011a). Whether the source of the interferon is plasmacytoid dendritic cells, natural killer cells, or some other cell type remains to be determined. In vivo, the antiviral activity of anti-NP antibody is partially dependent on activating Fc receptors expressed on hematopoietic cells (LaMere et al., 2011a). Thus, the antiviral reactions of this antibody may begin with the formation of immune complexes once NP is released from infected cells (Figure 4). Such immune complexes would then be capable of engaging $\mathrm{Fc}$ receptors on one or more effector

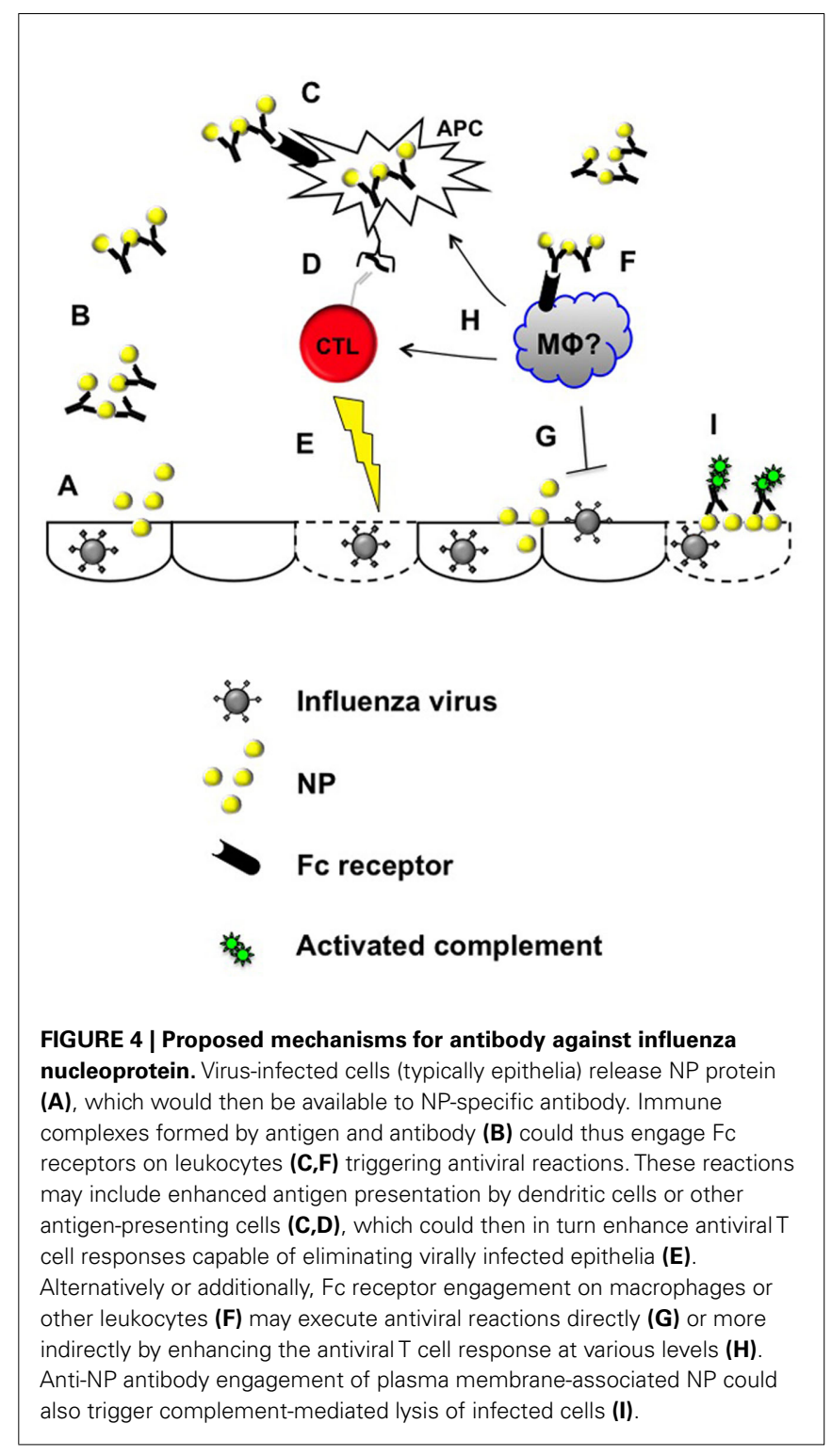

leukocytes, that would then trigger further reactions to eliminate virions and/or virally infected cells. Whether the candidate leukocytes are macrophages or some other cell type remains to be determined.

When immune complexes consisting of antibody with cognate antigen (including anti-NP with NP protein) bind to Fc receptors on dendritic cells, they can enhance dendritic cell activation and antigen-presenting activity in vitro (Regnault et al., 1999; Rodriguez et al., 1999; Machy et al., 2000; Dhodapkar et al., 2002; Bergtold et al., 2005; Groh et al., 2005; Harbers et al., 2007; Zheng et al., 2007). Furthermore, anti-NP antibody can enhance NPspecific $\mathrm{T}$ cell responses when injected into mice, detected as either cytotoxic T cell activity (Zheng et al., 2007) or by flow cytometry as MHC-NP peptide-binding $\mathrm{CD} 8^{+} \mathrm{T}$ cells (LaMere et al., 2011a). Notably, when NP-immune antibody is transferred into $\mathrm{T}$ cell-deficient mice or into mice depleted of $\mathrm{CD}^{+}$cells, its antiviral activity is reduced or abrogated (Mozdzanowska et al., 1999; 
Zharikova et al., 2005; Carragher et al., 2008; LaMere et al., 2011a). Thus, the antiviral mechanism of this antibody involves both Fc receptors and $\mathrm{T}$ cells, suggesting that immune complex stimulation of antigen presentation through these receptors may enhance cytotoxic $\mathrm{T}$ cell responses that can eliminate virus (Figure 4). In support of this mechanism, optimal heterosubtypic immunity correlates with both NP-specific CD8 T cell responses as well as anti-NP IgG responses (Rangel-Moreno et al., 2008; LaMere et al., 2011a). Importantly, antiviral mechanisms triggered by immune complex formation or by recognition of cell-bound NP would not require direct antibody engagement with replication-competent virus. Thus, unlike the antibodies described above, anti-NP antibody would be highly unlikely to provide a selective pressure for viral immune evasion.

Experimental infection of laboratory animals with influenza virus induces an NP-reactive serum IgG response within 2 weeks (Epstein et al., 1997; Kim et al., 2006; Rangel-Moreno et al., 2008; LaMere et al., 2011a,b). NP-reactive antibody can also be detected in most human subjects (Cretescu et al., 1978; Sukeno et al., 1979; Yamane et al., 1981; Ennis et al., 1982; Khurana et al., 2009; LaMere et al., 2011b), likely due to some prior exposure to influenza virus. In fact, the early transient antibody-secreting cell response in mice and humans during the first week of infection includes reactivity to NP (LaMere et al., 2011a; Lee et al., 2011). Whether this response is induced by soluble NP released during infection (LaMere et al., 2011a) or cell surface-associated NP during infection (Yewdell et al., 1981) is unknown. It was originally assumed that this antibody contributed little, if at all, to accelerated clearance of subsequent exposure to $\mathrm{HN}$-disparate viruses (heterosubtypic immunity). However, mice with defective antibody production or defective $\mathrm{B}$ cell development have poor heterosubtypic immunity (Nguyen et al., 2007; RangelMoreno et al., 2008; LaMere et al., 2011a), which in the latter case, can be rescued by injection with anti-NP IgG (LaMere et al., 2011a).

Given the antiviral activity of this antibody and its contribution to mouse heterosubtypic immunity, why then, does the human population with anti-NP IgG remain susceptible to influenzamediated illness? On one hand, the antiviral mechanisms functional in mice may simply not be present or sufficient in humans. Alternatively, the antiviral activity may go undetected, as no studies to-date have measured anti-NP antibody as a function of infection frequency, viral shedding, or signs of influenza-like illness. It may also be the case that the levels of this antibody are simply too low in some individuals. In mice, injection of purified anti-NP IgG requires a final equilibrated serum titer of $10^{5}$ to reduce viral load (LaMere et al., 2011a), but serum titers in humans tend to be at least 10-fold lower (LaMere et al., 2011b). The relative functional equivalence of these values among species is unknown, but the results nonetheless suggest that high titers of this antibody are necessary for antiviral efficacy.

An additional factor in the efficacy of anti-NP antibody may be the availability of antiviral CD8 $\mathrm{T}$ cells with which these antibodies need to cooperate (possibly as a direct part of the antibody's mechanism; Mozdzanowska et al., 1999; Zharikova et al., 2005; Carragher et al., 2008; LaMere et al., 2011a). Influenzaspecific $T$ cell immunity wanes significantly over time (McMichael et al., 1983; Liang et al., 1994). Thus, the efficacy of antiNP antibody may vary in different individuals depending on their serum titer, together with how recent the previous infection was, in addition to other unidentified factors. In this case, vaccination strategies to boost existing anti-NP antibody titers may extend or rejuvenate poor long-lived heterosubtypic immunity. In fact, boosting influenza H3N2 virus-immune mice with purified NP protein can accelerate viral clearance after subsequent H1N1 challenge, correlating with increased titers of antiNP IgG (LaMere et al., 2011b). This effect can be recapitulated by passive transfer of the antibody prior to challenge (LaMere et al., 2011b). Furthermore, anti-NP IgG can rescue diminished mouse heterosubtypic immunity up to 1.5 years after the primary infection (LaMere et al., 2011b). Thus, vaccination strategies to boost existing levels of anti-NP antibody may be a very feasible approach to inducing long-lived resistance to all influenza A strains.

Interestingly, despite abundant NP content in seasonal TIV, annual immunizations typically do not boost existing anti-NP antibody levels in humans (Ennis et al., 1982; LaMere et al., 2011b). Unadjuvanted TIV, as given to humans, also poorly induces antiNP antibody in influenza-naïve mice (LaMere et al., 2011b). Thus, vaccine strategies to boost this effective antiviral immunoglobulin would need to be in a different form from the current vaccines, such as purified protein. It is unknown if live, coldadapted influenza vaccine (FluMist ${ }^{\oplus}$ ) induces serum or mucosal antibody against NP in humans. However, intranasal vaccination with cold-adapted virus induces anti-NP (but not anti-M2e) antibody in mice, correlating with protection against lethal heterosubtypic challenge (Lo et al., 2008; Price et al., 2009; Soboleski et al., 2011). Whether such cross-protective effects correlate with anti-NP antibody levels in human FluMist ${ }^{\circledast}$ recipients remains to be determined.

Overall, the evidence from mice indicates that antibodies against the conserved antigens M2e and NP are highly effective against multiple influenza A strains. Because the development and use of influenza vaccines were, for many decades, focused on antibodies against the ever-changing external viral antigens, seriously shifting our efforts toward greater cross-protection by human vaccination focused on these more conserved antigens would be a revolutionary advance.

\section{ANTIBODIES REACTIVE WITH OTHER INFLUENZA VIRUS ANTIGENS}

As discussed above, strong experimental data indicate that HAIindependent antibodies against HA stalk domain, against M2e, and against NP have clear advantages over HAI-competent antibodies in controlling influenza infections because they can recognize more viral strains and are less likely to promote high-rate immune evasion (Table 2). It has additionally been argued that sterilizing neutralization mechanisms that rapidly eliminate challenge virus before the adaptive immune system can respond effectively prevent the induction of heterosubtypic immunity (Bodewes et al., 2009, 2010). Thus, carefully choosing which antiviral antibodies to induce may allow optimization of the most effective long-term cross-protective responses. With this concept in-mind, developing strategies to induce such antibodies should consider whether 
Table 2 | Comparison of antiviral antibodies showing efficacy against influenza virus.

\begin{tabular}{|c|c|c|c|c|c|}
\hline $\begin{array}{l}\text { Target } \\
\text { antigen }\end{array}$ & $\begin{array}{l}\text { In vitro } \\
\text { mechanism }\end{array}$ & $\begin{array}{l}\text { In vivo } \\
\text { requirements }\end{array}$ & Immunogenicity & Advantages & Disadvantages \\
\hline HA head & $\begin{array}{l}\text { Prevent receptor } \\
\text { binding }\end{array}$ & $\begin{array}{l}\text { T and B } \\
\text { cell-independent }\end{array}$ & $\begin{array}{l}\text { Good with infection, inactivated } \\
\text { virus, or DNA/viral vectors }\end{array}$ & True barrier of infection & $\begin{array}{l}\text { Poor cross-protection; strong } \\
\text { selection for immune evasion }\end{array}$ \\
\hline HA stalk & $\begin{array}{l}\text { Inhibit membrane } \\
\text { fusion }\end{array}$ & Unknown & $\begin{array}{l}\text { Good with (pandemic) infection, } \\
\text { DNA prime with TIV boost, or } \\
\text { long } \alpha \text { helix fused to KLH }\end{array}$ & $\begin{array}{l}\text { Cross-protection among } \\
\text { HA subtypes within a } \\
\text { group }\end{array}$ & $\begin{array}{l}\text { Less protective between HA } \\
\text { groups; selection possible }\end{array}$ \\
\hline NA & $\begin{array}{l}\text { Prevent virion } \\
\text { release }\end{array}$ & $\begin{array}{l}\text { T and B } \\
\text { cell-independent }\end{array}$ & $\begin{array}{l}\text { Good with infection, inactivated } \\
\text { virus, or DNA/viral vectors }\end{array}$ & $\begin{array}{l}\text { Prevents early virus } \\
\text { spread }\end{array}$ & $\begin{array}{l}\text { Selection possible (?); appear } \\
\text { to be less efficacious than } \\
\text { other antibodies }\end{array}$ \\
\hline $\mathrm{M} 2 \mathrm{e}$ & $\begin{array}{l}\text { Prevent virion } \\
\text { release }\end{array}$ & $\begin{array}{l}\text { T and B } \\
\text { cell-independent; } \\
\text { needs FcR; can } \\
\text { function through FcR } \\
\text { on } \mathrm{M} \phi\end{array}$ & $\begin{array}{l}\text { Poor with infection or } \\
\text { inactivated virus; Good with } \\
\text { protein fusion or DNA/viral } \\
\text { vectors }\end{array}$ & $\begin{array}{l}\text { Cross-protective among } \\
\text { human and mouse } \\
\text { viruses }\end{array}$ & $\begin{array}{l}\text { Some selection possible; } \\
\text { alone works poorly against H5 } \\
\text { avian viruses if not matched at } \\
\text { aa P10 }\end{array}$ \\
\hline NP & $\begin{array}{l}\text { Stimulate DC } \\
\text { activation; stimulate } \\
\text { complement- } \\
\text { mediated } \\
\text { cytolysis }\end{array}$ & $\begin{array}{l}\text { Optimal activity } \\
\text { requires FcR on } \\
\text { leukocytes and T } \\
\text { cells/CD8+ cells }\end{array}$ & $\begin{array}{l}\text { Good with infection, purified } \\
\text { protein, or DNA/viral vectors; } \\
\text { poor with inactivated virus }\end{array}$ & $\begin{array}{l}\text { Reacts with all influenza } \\
\text { A sequences; } \\
\text { mechanism unlikely } \\
\text { requires association } \\
\text { with virion (unlikely to } \\
\text { promote selection) }\end{array}$ & High titers of antibody needed \\
\hline NS1 & Unknown & Unknown & $\begin{array}{l}\text { Good with infection; poor with } \\
\text { protein immunization }\end{array}$ & $\begin{array}{l}\text { Not associated with } \\
\text { virion (unlikely to } \\
\text { promote selection) }\end{array}$ & $\begin{array}{l}\text { Moderate conservation of } \mathrm{Ag} \\
\text { among viral strains }\end{array}$ \\
\hline
\end{tabular}

FCR, FC receptors; TIV, trivalent-inactivated influenza vaccine; $K L H$, keyhole limpet hemocyanin; M $\phi$, macrophages; Ag, antigen; DC, dendritic cell.

Table 3 | Antibodies with unknown efficacy against influenza virus.

\begin{tabular}{ll}
\hline Target antigen & Reported in serum samples \\
\hline M1 & Mouse infection; swine infection; H5N1-convalescent \\
& human serum; rare in human volunteers experimentally \\
& infected \\
& H5N1-convalescent human serum \\
PB1 & H5N1-convalescent human serum \\
PB2 & H5N1-convalescent human serum; infected mice; \\
PB1-F2 & seasonal-convalescent human serum \\
& H5N1-convalescent human serum \\
NS2 & H5N1-convalescent human serum; swine infection
\end{tabular}

additional influenza-reactive antibodies (Table 3) could make further contributions.

Influenza matrix 1 (M1) protein, which constitutes the influenza viral coat, is $>90 \%$ conserved at the amino-acid level among examined sequences (Lamb and Lai, 1981; Ito et al., 1991; Berthoud et al., 2011). Thus, antibody reactions against M1 would be expected to recognize multiple viral serotypes. Like anti$\mathrm{NP}$, anti-M1 antibody is induced by influenza infection of mice (Johansson et al., 1987) and swine (Kim et al., 2006). In one study, M1-specific antibody has been detected in convalescent serum from 5 of 5 H5N1 survivors (Khurana et al., 2009). However, an experimental human infection-induced a rise in anti-M1 in only $\sim 4 \%$ of volunteers, few of whom began with anti-M1 antibody; by contrast, anti-NP antibody was much more common at baseline, and $14.2 \%$ of volunteers had a rise in anti-NP after infection (Cretescu et al., 1978). Whether the less common induction of anti-M1 results from less or differential exposure of the antigen to B cells during infection is unknown. Unlike NP (Virelizier et al., 1977; Yewdell et al., 1981), M1 has not been detected on the surface of infected cells in culture (Mozdzanowska et al., 1999). It is unknown whether anti-M1 antibody is capable of antiviral activity. One tested monoclonal antibody against M1 neither neutralized virus in vitro nor cleared virus from infected scid mice (Mozdzanowska et al., 1999). However, it cannot be excluded that like anti-NP, this antibody could have antiviral activity at higher titers and/or in the presence of $\mathrm{T}$ lymphocytes.

The non-structural 1 (NS1) influenza gene product is expressed in infected cells, but not in virions (Hale et al., 2008). NS1 is a multifunctional virulence factor that disrupts the interferon response to virus, in addition to other mechanisms (Hale et al., 2008). Antibody against this protein is induced after influenza infection in mice (LaMere et al., 2011a,b), swine (Kim et al., 2006), and human (Khurana et al., 2009). Although induction of anti-NS1 antibody through active vaccination of influenza-naïve mice had little effect on viral clearance in our hands (unpublished), boosting existing levels of antibody induced by previous infection correlated with an early increase in viral load after challenge infection (LaMere et al., 2011a). However, preliminary results suggest that such boosting can reduce viral titers at 1 week, and that this effect can be transferred by immune serum (unpublished). The amino-acid identity of NS1 among most human influenza strains is reported to be greater than $93 \%$, although these differ from avian strains by up to 
40\% (Hale et al., 2008; Kuo et al., 2010). Thus, the antiviral capabilities of anti-NS1 antibodies might be limited in instances of zoonotic transmission of the latter viruses. As a non-virion protein, however, any antiviral reactions of these antibodies would be highly unlikely to select for escape-mutant viruses. Antibodies against the NS1 splice variant, NS2, are also induced after influenza infection (Kim et al., 2006; Khurana et al., 2009); however, their antiviral potential is unknown.

Antibody against the influenza RNA polymerase subunits PA, $\mathrm{PB} 1, \mathrm{~PB} 2$, and against the reading frame-shift product of the PB1 RNA genome segment called PB1-F2 have been detected in humans and mice known or likely to have been exposed to influenza infection (Khurana et al., 2009; Krejnusova et al., 2009). To our knowledge, antiviral activity of such antibodies has not been tested. The putative efficacy of anti-PA antibody could depend on whether it is capable of inducing corresponding specific $\mathrm{T}$ cell responses, as is the case with anti-NP antibody. Unlike virusreducing NP-specific T cells, PA-specific T cells can increase viral load in virus-challenged mice (Crowe et al., 2005, 2006). Thus, antibodies against PA may result in proviral conditions. A T cellindependent antiviral role for any polymerase-specific antibodies cannot be excluded, however.

Overall, newly appreciated antiviral activities of antibodies against HA stalk, M2e, and NP (Table 2), possibly in addition to other less-explored reactivities (Table 3 ) provide diverse opportunities for developing more cross-protective, and conceivably universal, influenza vaccines. Whether such strategies will be optimal alone, in combination with HAI antibodies, or with each other remains to be determined. Vaccination with a combination of M1 and NP DNA in a modified vaccinia vector was recently demonstrated to be safe and to induce antigen-specific $\mathrm{T}$ cell responses in a human phase-I trial (Berthoud et al., 2011). Follow-up trials should include an analysis of anti-M1 and anti-NP antibody in the context of virus attack rate, viral load, and influenza-like illness in vaccinated compared with control subjects. Testing different formulations to optimize long-lived serum antibody against these antigens, such as whole protein immunization, can also be compared in the future.

One important consideration for formulation and scheduling approaches to induce multiple antibodies against influenza virus is the fact that one antigen may influence the immunogenicity of another. In chickens, HAI and neutralizing activity induced by HA DNA vaccination with a Newcastle disease virus vector can be

\section{REFERENCES}

(1989). Oxford English Dictionary. Available at: http://www.oed.com/ view/Entry/95531?redirectedFrom= influenza\#eid

(2011). Review of the 2010-2011 winter influenza season, northern hemisphere. Wkly. Epidemiol. Rec. 86, 222-227. (PMID 21661271).

Ahmad, R., Sindhu, S. T., Toma, E., Morisset, R., Vincelette, J., Menezes, J., and Ahmad, A. (2001). Evidence for a correlation between antibody-dependent cellular cytotoxicity-mediating anti-HIV-1

inhibited by co-vaccination with an M2-encoding vector (Nayak et al., 2010). Reciprocally, NA and/or HA co-immunization can inhibit chicken antibody responses to M2 as well (Nayak et al., 2010). These effects on antibody levels correlate with the relative efficacy of the respective vaccinations against highly pathogenic influenza viral load and host animal survival (Nayak et al., 2010). It is unknown if the inhibitory effects of M2 with HA and NA immunogenicity are due to responses to the antigens per se, or due to these vectors influencing each others' gene product expression.

Seasonal TIV (consisting of proteins from whole, inactivated, detergent-split virus) induces little anti-NP antibody in mice; however, TIV together with purified NP protein at a low dose that does not induce anti-NP antibody on its own, induces a strong anti-NP response (LaMere et al., 2011b). By contrast, anti-NP IgG titers induced by high-dose NP protein can be suppressed by high doses of TIV (LaMere et al., 2011b). Thus, the stoichiometry of NP with other TIV components can influence the antibody response to NP protein. It is unknown which TIV component(s) confer this effect. Such considerations, as well as further animal and human trials will be needed to develop optimal immunogenicity protocols for protective influenza antigens.

Although influenza was initially named based on an erroneously concluded causality (1989; Gerdil, 2003), this disease clearly "influences" human civilization in profound ways ( $\mathrm{Li}$ and Leader, 2007; Molinari et al., 2007; Nichol et al., 2009; Nichol, 2011). In turn, we have put enormous effort into countering influenza virus with an immune mechanism that fails to keep pace with, and can even drive viral escape. The recent influenza pandemic of 2009, together with abundant animal reservoirs of new viral serotypes, some of which are highly pathogenic, illustrate a pressing need to change the course of our approach. To this end, exploitable mechanisms that are more cross-protective and are much less likely to promote viral escape can be mediated by antibodies against multiple viral antigens. Clearly, we have a great capacity to "influence" our own fate by applying the experimental findings about these antibodies to practical human use.

\section{ACKNOWLEDGMENTS}

The authors were supported by NIH AI079537 to Denise A. Kaminski and N01-AI50029 to F. Eun-Hyung Lee. We thank Drs. Frances Lund and Ravi Misra for reading the manuscript, and Eric Ho-Tak Lam for sharing unpublished data on NS1-immune antibody.

influenza in healthy adults: a prospective, randomized, placebocontrolled trial. J. Infect. Dis. 200, 1861-1869.

Bergtold, A., Desai, D. D., Gavhane, A., and Clynes, R. (2005). Cell surface recycling of internalized antigen permits dendritic cell priming of B cells. Immunity 23, 503-514.

Berthoud, T. K., Hamill, M., Lillie, P. J., Hwenda, L., Collins, K. A., Ewer, K. J., Milicic, A., Poyntz, H. C., Lambe, T., Fletcher, H. A., Hill, A. V., and Gilbert, S. C. (2011). Potent CD8+ T-cell immunogenicity in humans of a novel heterosubtypic influenza A vaccine, MVANP+M1. Clin. Infect. Dis. 52, $1-7$.

Bodewes, R., Kreijtz, J. H., Hillaire, M. L. Geelhoed-Mieras, M. M., Fouchier R. A., Osterhaus, A. D., and Rimmelzwaan, G. F. (2010). Vaccination with whole inactivated virus vaccine affects the induction of heterosubtypic immunity against influenza virus $\mathrm{A} / \mathrm{H} 5 \mathrm{~N} 1$ and immunodominance of virus-specific CD8+ T-cell responses in mice. J. Gen. Virol. 91, 1743-1753. 
Bodewes, R., Kreijtz, J. H., and Rimmelzwaan, G. F. (2009). Yearly influenza vaccinations: a doubleedged sword? Lancet. Infect. Dis. 9, 784-788.

Brett, I. C., and Johansson, B. E. (2005). Immunization against influenza A virus: comparison of conventional inactivated, live-attenuated and recombinant baculovirus produced purified hemagglutinin and neuraminidase vaccines in a murine model system. Virology 339, 273-280.

Brown, D. M., Dilzer, A. M., Meents, D. L., and Swain, S. L. (2006). CD4 T cell-mediated protection from lethal influenza: perforin and antibodymediated mechanisms give a onetwo punch. J. Immunol. 177, 2888-2898.

Carragher, D. M., Kaminski, D. A., Moquin, A., Hartson, L., and Randall, T. D. (2008). A novel role for non-neutralizing antibodies against nucleoprotein in facilitating resistance to influenza virus. J. Immunol. 181, 4168-4176.

Chehadeh, W., Bouzidi, A., Alm, G., Wattre, P., and Hober, D. (2001). Human antibodies isolated from plasma by affinity chromatography increase the coxsackievirus B4induced synthesis of interferonalpha by human peripheral blood mononuclear cells in vitro. J. Gen. Virol. 82, 1899-1907.

Corti, D., Suguitan, A. L. Jr., Pinna, D., Silacci, C., Fernandez-Rodriguez, B. M., Vanzetta, F., Santos, C., Luke, C. J., Torres-Velez, F. J., Temperton, N. J., Weiss, R. A., Sallusto, F., Subbarao, K., and Lanzavecchia, A. (2010). Heterosubtypic neutralizing antibodies are produced by individuals immunized with a seasonal influenza vaccine. J. Clin. Invest. 120, 1663-1673.

Corti, D., Voss, J., Gamblin, S. J., Codoni, G., Macagno, A., Jarrossay, D., Vachieri, S. G., Pinna, D., Minola, A., Vanzetta, F., Silacci, C., FernandezRodriguez, B. M., Agatic, G., Bianchi, S., Giacchetto-Sasselli, I., Calder, L., Sallusto, F., Collins, P., Haire, L. F., Temperton, N., Langedijk, J. P., Skehel, J. J., and Lanzavecchia, A. (2011). A neutralizing antibody selected from plasma cells that binds to group 1 and group 2 influenza A hemagglutinins. Science 333, 850-856.

Cretescu, L., Beare, A. S., and Schild, G. C. (1978). Formation of antibody to matrix protein in experimental human influenza A virus infections. Infect. Immun. 22, 322-327.
Crowe, S. R., Miller, S. C., Shenyo, R. M., and Woodland, D. L. (2005). Vaccination with an acidic polymerase epitope of influenza virus elicits a potent antiviral $\mathrm{T}$ cell response but delayed clearance of an influenza virus challenge. J. Immunol. 174, 696-701.

Crowe, S. R., Miller, S. C., and Woodland, D. L. (2006). Identification of protective and non-protective T cell epitopes in influenza. Vaccine 24, 452-456.

De Filette, M., Ysenbaert, T., Roose, K., Schotsaert, M., Roels, S., Goossens, E., Schepens, B., Fiers, W., and Saelens, X. (2011). Antiserum against the conserved nine amino acid $\mathrm{N}$ terminal peptide of influenza A virus matrix protein 2 is not immunoprotective. J. Gen. Virol. 92, 301-306.

Dhodapkar, K. M., Krasovsky, J., Williamson, B., and Dhodapkar, M. V. (2002). Antitumor monoclonal antibodies enhance crosspresentation of cellular antigens and the generation of myeloma-specific killer T cells by dendritic cells. J. Exp. Med. 195, 125-133.

Du, L., Zhou, Y., and Jiang, S. (2010). Research and development of universal influenza vaccines. Microbes Infect. 12, 280-286.

Ekiert, D. C., Bhabha, G., Elsliger, M. A., Friesen, R. H., Jongeneelen, M., Throsby, M., Goudsmit, J., and Wilson, I. A. (2009). Antibody recognition of a highly conserved influenza virus epitope. Science 324, 246-251.

Ekiert, D. C., Friesen, R. H., Bhabha, G., Kwaks, T., Jongeneelen, M., Yu, W., Ophorst, C., Cox, F., Korse, H. J., Brandenburg, B., Vogels, R., Brakenhoff, J. P., Kompier, R., Koldijk, M. H., Cornelissen, L. A., Poon, L. L., Peiris, M., Koudstaal, W., Wilson, I. A., and Goudsmit, J. (2011). A highly conserved neutralizing epitope on group 2 influenza A viruses. Science 333, 843-850.

El Bakkouri, K., Descamps, F., De Filette, M., Smet, A., Festjens, E., Birkett, A., Van Rooijen, N., Verbeek, S., Fiers, W., and Saelens, X. (2011). Universal vaccine based on ectodomain of matrix protein 2 of influenza A: Fc receptors and alveolar macrophages mediate protection. J. Immunol. 186, 1022-1031.

Ennis, F. A., Yi-Hua, Q., and Schild, G. C. (1982). Antibody and cytotoxic T lymphocyte responses of humans to live and inactivated influenza vaccines. J. Gen. Virol. 58, 273-281.

Epstein, S. L., Kong, W. P., Misplon, J. A., Lo, C. Y., Tumpey, T. M., Xu, L., and Nabel, G. J. (2005). Protection against multiple influenza A subtypes by vaccination with highly conserved nucleoprotein. Vaccine 23, 5404-5410.

Epstein, S. L., Lo, C. Y., Misplon, J. A., Lawson, C. M., Hendrickson, B. A., Max, E. E., and Subbarao, K. (1997). Mechanisms of heterosubtypic immunity to lethal influenza A virus infection in fully immunocompetent, T cell-depleted, b2-microglobulin-deficient, and J chain-deficient mice. J. Immunol. 158, 1222-1230.

Epstein, S. L., Stack, A., Misplon, J. A., Lo, C. Y., Mostowski, H., Bennink, J., and Subbarao, K. (2000). Vaccination with DNA encoding internal proteins of influenza virus does not require $\mathrm{CD} 8(+)$ cytotoxic $\mathrm{T}$ lymphocytes: either $\mathrm{CD} 4(+)$ or $\mathrm{CD} 8(+) \mathrm{T}$ cells can promote survival and recovery after challenge. Int. Immunol. 12, 91-101.

Ernst, W. A., Kim, H. J., Tumpey, T. M., Jansen, A. D., Tai, W. Cramer, D. V., Adler-Moore, J. P., and Fujii, G. (2006). Protection against $\mathrm{H} 1, \mathrm{H} 5$, $\mathrm{H} 6$ and $\mathrm{H} 9$ influenza A infection with liposomal matrix 2 epitope vaccines. Vaccine 24 5158-5168.

Feng, J., Zhang, M., Mozdzanowska, K. Zharikova, D., Hoff, H., Wunner, W., Couch, R. B., and Gerhard, W (2006). Influenza A virus infection engenders a poor antibody response against the ectodomain of matrix protein 2. Virol. J. 3, 102.

Forthal, D. N., Landucci, G., and Daar, E. S. (2001). Antibody from patients with acute human immunodeficiency virus (HIV) infection inhibits primary strains of HIV type 1 in the presence of naturalkiller effector cells. J. Virol. 75, 6953-6961.

Fraser, C., Donnelly, C. A., Cauchemez, S., Hanage, W. P., Van Kerkhove, M. D., Hollingsworth, T. D., Griffin, J., Baggaley, R. F., Jenkins, H. E., Lyons, E. J., Jombart, T., Hinsley, W. R. Grassly, N. C., Balloux, F., Ghani, A. C., Ferguson, N. M., Rambaut, A., Pybus, O. G., Lopez-Gatell, H., Alpuche-Aranda, C. M., Chapela, I. B., Zavala, E. P., Guevara, D. M., Checchi, F., Garcia, E., Hugonnet, S., Roth, C., and Collaboration, W. H. O. R. P. A. (2009). Pandemic potential of a strain of influenza A (H1N1): early findings. Science 324 1557-1561.

Fu, T. M., Guan, L., Friedman, A., Schofield, T. L., Ulmer, J. B., Liu, M. A., and Donnelly, J. J. (1999). Dose dependence of CTL precursor frequency induced by a DNA vaccine and correlation with protective immunity against influenza virus challenge. J. Immunol. 162, 4163-4170.

Gabbard, J., Velappan, N., Di Niro, R., Schmidt, J., Jones, C. A., Tompkins, S. M., and Bradbury, A. R. (2009). A humanized anti-M2 scFv shows protective in vitro activity against influenza. Protein Eng. Des. Sel. 22, 189-198.

Gamblin, S. J., and Skehel, J. J. (2010). Influenza hemagglutinin and neuraminidase membrane glycoproteins. J. Biol. Chem. 285, 28403-28409.

Gerdil, C. (2003). The annual production cycle for influenza vaccine. Vaccine 21, 1776-1779.

Gomez-Roman, V. R., Patterson, L. J., Venzon, D., Liewehr, D., Aldrich, K., Florese, R., and Robert-Guroff, M. (2005). Vaccine-elicited antibodies mediate antibody-dependent cellular cytotoxicity correlated with significantly reduced acute viremia in rhesus macaques challenged with SIVmac251. J. Immunol. 174, 2185-2189.

Groh, V., Li, Y. Q., Cioca, D., Hunder, N. N., Wang, W., Riddell, S. R., Yee, C., and Spies, T. (2005). Efficient crosspriming of tumor antigen-specific $\mathrm{T}$ cells by dendritic cells sensitized with diverse anti-MICA opsonized tumor cells. Proc. Natl. Acad. Sci. U.S.A. 102, 6461-6466.

Hale, B. G., Randall, R. E., Ortin, J., and Jackson, D. (2008). The multifunctional NS1 protein of influenza A viruses. J. Gen. Virol. 89, 2359-2376.

Halliley, J. L., Kyu, S., Kobie, J. J., Walsh, E. E., Falsey, A. R., Randall, T. D., Treanor, J., Feng, C., Sanz, I., and Lee, F. E. (2010). Peak frequencies of circulating human influenza-specific antibody secreting cells correlate with serum antibody response after immunization. Vaccine 28, 3582-3587.

Han, T., and Marasco, W. A. (2011). Structural basis of influenza virus neutralization. Ann. N. Y. Acad. Sci. 1217, 178-190.

Hancock, K., Veguilla, V., Lu, X., Zhong, W., Butler, E. N., Sun, H., Liu, F., Dong, L., DeVos, J. R., Gargiullo, P. M., Brammer, T. L., Cox, N. J., Tumpey, T. M., and Katz, J. M. (2009). Cross-reactive antibody responses to the 2009 pandemic H1N1 influenza virus. N. Engl. J. Med. 361, 1945-1952.

Harbers, S. O., Crocker, A., Catalano, G., D'Agati, V., Jung, S., Desai, D. D., and Clynes, R. (2007). Antibody-enhanced crosspresentation of self antigen breaks $\mathrm{T}$ cell tolerance. J. Clin. Invest. 117, 1361-1369. 
Hensley, S. E., Das, S. R., Bailey, A. L., Schmidt, L. M., Hickman, H. D., Jayaraman, A., Viswanathan, K., Raman, R., Sasisekharan, R., Bennink, J. R., and Yewdell, J. W. (2009). Hemagglutinin receptor binding avidity drives influenza A virus antigenic drift. Science 326, 734-736.

Hessell, A. J., Hangartner, L., Hunter, M., Havenith, C. E., Beurskens, F. J., Bakker, J. M., Lanigan, C. M., Landucci, G., Forthal, D. N., Parren, P. W., Marx, P. A., and Burton, D. R. (2007). Fc receptor but not complement binding is important in antibody protection against HIV. Nature 449, 101-104.

Hober, D., Chehadeh, W., Bouzidi, A., and Wattre, P. (2001). Antibodydependent enhancement of coxsackievirus B4 infectivity of human peripheral blood mononuclear cells results in increased interferonalpha synthesis. J. Infect. Dis. 184, 1098-1108.

Hutchinson, E. C., von Kirchbach, J. C., Gog, J. R., and Digard, P. (2010). Genome packaging in influenza A virus. J. Gen. Virol. 91, 313-328.

Ito, T., Gorman, O. T., Kawaoka, Y., Bean, W. J., and Webster, R. G. (1991). Evolutionary analysis of the influenza A virus $\mathrm{M}$ gene with comparison of the M1 and M2 proteins. J. Virol. 65, 5491-5498.

Itoh, Y., Shinya, K., Kiso, M., Watanabe, T., Sakoda, Y., Hatta, M., Muramoto, Y. T. D., Sakai-Tagawa, Y., Noda, T., Sakabe, S., Imai, M., Hatta, Y., Watanabe, S., Li, C., Yamada, S., Fujiii, K., Murakami, S., Imai, H., Kakugawa, S., Ito, M., Takano, R., Iwatsuki-Horimoto, K., Shimojima, M., Horimoto, T., Goto, H., Takahashi, K., Makino, A., Ishigaki, H., Nakayama, M., Okamatsu, M., Takahashi, K., Warshauer, D., Shult, P. A., Saito, R., Suzuki, H., Furuta, Y., Yamashita, M., Mitamura, K., Nakano, K., Nakamura, M., Brockman-Schneider, R., Mitamura, H., Yamazaki, M., Sugaya, N., Suresh, M., Ozawa, M., Neumann, G., Gern, J., Kida, H., Ogasawara, K., and Kawaoka, Y. (2009). In vitro and in vivo characterization of new swine-origin H1N1 influenza viruses. Nature 460, 1021-1025.

Jackson, L. A., Gaglani, M. J., Keyserling, H. L., Balser, J., Bouveret, N., Fries, L., and Treanor, J. J. (2010). Safety, efficacy, and immunogenicity of an inactivated influenza vaccine in healthy adults: a randomized, placebocontrolled trial over two influenza seasons. BMC Infect. Dis. 10, 71. doi:10.1186/1471-2334-10-71

Jegerlehner, A., Schmitz, N., Storni, T., and Bachmann, M. F. (2004). Influenza A vaccine based on the extracellular domain of $\mathrm{M} 2$ : weak protection mediated via antibodydependent NK cell activity. $J$. Immunol. 172, 5598-5605.

Johansson, B. E., and Kilbourne, E. D. (1993). Dissociation of influenza virus hemagglutinin and neuraminidase eliminates their intravirionic antigenic competition. J. Virol. 67, 5721-5723.

Johansson, B. E., Matthews, J. T., and Kilbourne, E. D. (1998). Supplementation of conventional influenza A vaccine with purified viral neuraminidase results in a balanced and broadened immune response. Vaccine 16, 1009-1015.

Johansson, B. E., Moran, T. M., Bona, C. A., Popple, S. W., and Kilbourne, E. D. (1987). Immunologic response to influenza virus neuraminidase is influenced by prior experience with the associated viral hemagglutinin. II. Sequential infection of mice simulates human experience. J. Immunol. 139, 2010-2014.

Khurana, S., Suguitan, A. L. Jr., Rivera, Y., Simmons, C. P., Lanzavecchia, A., Sallusto, F., Manischewitz, J., King, L. R., Subbarao, K., and Golding, H. (2009). Antigenic fingerprinting of $\mathrm{H} 5 \mathrm{~N} 1$ avian influenza using convalescent sera and monoclonal antibodies reveals potential vaccine and diagnostic targets. PLoS Med. 6, e1000049. doi:10.1371/journal.pmed.1000049

Kim, W. I., Wu, W. H., Janke, B., and Yoon, K. J. (2006). Characterization of the humoral immune response of experimentally infected and vaccinated pigs to swine influenza viral proteins. Arch. Virol. 151, 23-36.

Koopmans, M., Wilbrink, B., Conyn, M., Natrop, G., van der Nat, H., Vennema, H., Meijer, A., van Steenbergen, J., Fouchier, R., Osterhaus, A., and Bosman, A. (2004). Transmission of H7N7 avian influenza A virus to human beings during a large outbreak in commercial poultry farms in the Netherlands. Lancet $363,587-593$.

Korteweg, C., and Gu, J. (2008). Pathology, molecular biology, and pathogenesis of avian influenza A (H5N1) infection in humans. Am. J. Pathol. $172,1155-1170$

Krause, J. C., Tumpey, T. M., Huffman, C. J., McGraw, P. A., Pearce, M. B., Tsibane, T., Hai, R., Basler, C. F., and Crowe, J. E. Jr. (2010). Naturally occurring human monoclonal antibodies neutralize both
1918 and 2009 pandemic influenza A (H1N1) viruses. J. Virol. 84 3127-3130.

Krejnusova, I., Gocnikova, H., Bystricka, M., Blaskovicova, H., Polakova, K. Yewdell, J., Bennink, J., and Russ, G. (2009). Antibodies to PB1-F2 protein are induced in response to influenza A virus infection. Arch. Virol. 154, 1599-1604.

Kuo, R. L., Zhao, C., Malur, M., and Krug, R. M. (2010). Influenza A virus strains that circulate in humans differ in the ability of their NS1 proteins to block the activation of IRF3 and interferon-beta transcription. Virology 408, 146-158.

Lamb, R. A., and Lai, C. J. (1981). Conservation of the influenza virus membrane protein (M1) amino acid sequence and an open reading frame of RNA segment 7 encoding a second protein (M2) in $\mathrm{H} 1 \mathrm{~N} 1$ and $\mathrm{H} 3 \mathrm{~N} 2$ strains. Virology 112, 746-751.

Lamb, R. A., Zebedee, S. L., and Richardson, C. D. (1985). Influenza virus M2 protein is an integral membrane protein expressed on the infectedcell surface. Cell 40, 627-633.

LaMere, M. W., Lam, H. T., Moquin, A., Haynes, L., Lund, F. E., Randall, T. D., and Kaminski, D. A. (2011a). Contributions of antinucleoprotein IgG to heterosubtypic immunity against influenza virus. J. Immunol. 186 4331-4339.

LaMere, M. W., Moquin, A., Lee, F. E., Misra, R. S., Blair, P. J., Haynes, L., Randall, T. D., Lund, F. E., and Kaminski, D. A. (2011b). Regulation of antinucleoprotein IgG by systemic vaccination and its effect on influenza virus clearance. J. Virol. 85 , 5027-5035.

Lee, F. E., Halliley, J. L., Walsh, E. E., Moscatiello, A. P., Kmush, B. L., Falsey, A. R., Randall, T. D., Kaminski, D. A., Miller, R. K., and Sanz, I. (2011). Circulating human antibody-secreting cells during vaccinations and respiratory viral infections are characterized by high specificity and lack of bystander effect. $J$. Immunol. 186, 5514-5521.

Li, S., and Leader, S. (2007). Economic burden and absenteeism from influenza-like illness in healthy households with children (5-17 years) in the US. Respir. Med. 101, 1244-1250.

Liang, S., Mozdzanowska, K., Palladino, G., and Gerhard, W. (1994). Heterosubtypic immunity to influenza type A virus in mice. Effector mechanisms and their longevity. $J$. Immunol. 152, 1653-1661.

Lo, C. Y., Wu, Z., Misplon, J. A., Price, G. E., Pappas, C., Kong, W. P., Tumpey, T. M., and Epstein, S. L.
(2008). Comparison of vaccines for induction of heterosubtypic immunity to influenza A virus: coldadapted vaccine versus DNA primeadenovirus boost strategies. Vaccine 26, 2062-2072.

Machy, P., Serre, K., and Leserman, L. (2000). Class I-restricted presentation of exogenous antigen acquired by Fcg-mediated endocytosis is regulated in dendritic cells. Eur. J. Immunol. 30, 848-857.

McMichael, A. J., Gotch, F. M., Dongworth, D. W., Clark, A., and Potter, C. W. (1983). Declining T-cell immunity to influenza, 1977-82. Lancet 2 , 762-764.

Medina, R. A., and Garcia-Sastre, A. (2011). Influenza A viruses: new research developments. Nat. Rev. Microbiol. 9, 590-603.

Misplon, J. A., Lo, C. Y., Gabbard, J. D., Tompkins, S. M., and Epstein, S. L. (2010). Genetic control of immune responses to influenza A matrix 2 protein (M2). Vaccine 28 5817-5827.

Molinari, N. A., Ortega-Sanchez, I. R., Messonnier, M. L., Thompson, W. W., Wortley, P. M., Weintraub, E., and Bridges, C. B. (2007). The annual impact of seasonal influenza in the US: measuring disease burden and costs. Vaccine 25, 5086-5096.

Mossad, S. B. (2007). Influenza update 2007-2008: vaccine advances, pandemic preparation. Cleve. Clin. J. Med. 74, 889-894.

Mossad, S. B. (2008). 2008-2009 Influenza update: a better vaccine match. Cleve. Clin. J. Med. 75, 865-870.

Mozdzanowska, K., Maiese, K., Furchner, M., and Gerhard, W. (1999). Treatment of influenza virus-infected SCID mice with nonneutralizing antibodies specific for the transmembrane proteins matrix 2 and neuraminidase reduces the pulmonary virus titer but fails to clear the infection. Virology 254, 138-146.

Murphy, B. R., Kasel, J. A., and Chanock, R. M. (1972). Association of serum anti-neuraminidase antibody with resistance to influenza in man. $N$. Engl. J. Med. 286, 1329-1332.

Nabel, G. J., Wei, C. J., and Ledgerwood, J. E. (2011). Vaccinate for the next $\mathrm{H} 2 \mathrm{~N} 2$ pandemic now. Nature 471, $157-158$.

Nayak, B., Kumar, S., DiNapoli, J. M., Paldurai, A., Perez, D. R., Collins, P. L., and Samal, S. K. (2010). Contributions of the avian influenza virus $\mathrm{HA}, \mathrm{NA}$, and M2 surface proteins to the induction of neutralizing antibodies and protective immunity. $J$. Virol. 84, 2408-2420. 
Neirynck, S., Deroo, T., Saelens, X., Vanlandschoot, P., Jou, W. M., and Fiers, W. (1999). A universal influenza A vaccine based on the extracellular domain of the M2 protein. Nat. Med. 5, 1157-1163.

Neumann, G., Noda, T., and Kawaoka, Y. (2009). Emergence and pandemic potential of swine-origin H1N1 influenza virus. Nature 459, 931-939.

Nguyen, H. H., Zemlin, M., Ivanov, I. I., Andrasi, J., Zemlin, C., Vu, H. L., Schelonka, R., Schroeder, H. W. Jr., and Mestecky, J. (2007). Heterosubtypic immunity to influenza A virus infection requires a properly diversified antibody repertoire. J. Virol. 81, 9331-9338.

Nichol, K. L. (2011). Cost-effectiveness and socio-economic aspects of childhood influenza vaccination. Vaccine 29, 7554-7558.

Nichol, K. L., D’Heilly, S. J., Greenberg, M. E., and Ehlinger, E. (2009). Burden of influenza-like illness and effectiveness of influenza vaccination among working adults aged 50-64 years. Clin. Infect. Dis. 48, 292-298.

Nichol, K. L., Nordin, J. D., Nelson, D. B., Mullooly, J. P., and Hak, E. (2007). Effectiveness of influenza vaccine in the community-dwelling elderly. $N$. Engl. J. Med. 357, 1373-1381.

Oh, H. L., Akerstrom, S., Shen, S., Bereczky, S., Karlberg, H., Klingstrom, J., Lal, S. K., Mirazimi, A., and Tan, Y. J. (2010). An antibody against a novel and conserved epitope in the hemagglutinin 1 subunit neutralizes numerous H5N1 influenza viruses. J. Virol. 84, 8275-8286.

Ohmit, S. E., Victor, J. C., Rotthoff, J. R., Teich, E. R., Truscon, R. K., Baum, L. L., Rangarajan, B., Newton, D. W., Boulton, M. L., and Monto, A. S. (2006). Prevention of antigenically drifted influenza by inactivated and live attenuated vaccines. N. Engl. J. Med. 355, 2513-2522.

Okuno, Y., Matsumoto, K., Isegawa, Y., and Ueda, S. (1994). Protection against the mouse-adapted $\mathrm{A} / \mathrm{FM} / 1 / 47$ strain of influenza $\mathrm{A}$ virus in mice by a monoclonal antibody with cross-neutralizing activity among $\mathrm{H} 1$ and $\mathrm{H} 2$ strains. J. Virol. 68, 517-520.

Palmer, P., Charley, B., Rombaut, B., Daeron, M., and Lebon, P. (2000). Antibody-dependent induction of type I interferons by poliovirus in human mononuclear blood cells requires the type II $\mathrm{Fc} \gamma$ receptor (CD32). Virology 278, 86-94.

Peiris, M., Yuen, K. Y., Leung, C. W., Chan, K. H., Ip, P. L., Lai, R. W., Orr,
W. K., and Shortridge, K. F. (1999). Human infection with influenza H9N2. Lancet 354, 916-917.

Portela, A., and Digard, P. (2002). The influenza virus nucleoprotein: a multifunctional RNA-binding protein pivotal to virus replication. $J$. Gen. Virol. 83, 723-734.

Potter, C. W. (2001). A history of influenza. J. Appl. Microbiol. 91, 572-579.

Powers, D. C., Kilbourne, E. D., and Johansson, B. E. (1996) Neuraminidase-specific antibody responses to inactivated influenza virus vaccine in young and elderly adults. Clin. Diagn. Lab. Immunol. 3, 511-516.

Price, G. E., Soboleski, M. R., Lo, C. Y., Misplon, J. A., Pappas, C., Houser, K. V., Tumpey, T. M., and Epstein, S. L. (2009). Vaccination focusing immunity on conserved antigens protects mice and ferrets against virulent $\mathrm{H} 1 \mathrm{~N} 1$ and $\mathrm{H} 5 \mathrm{~N} 1$ influenza A viruses. Vaccine 27, 6512-6521.

Rangel-Moreno, J., Carragher, D. M., Misra, R. S., Kusser, K., Hartson, L., Moquin, A., Lund, F. E., and Randall, T. D. (2008). B cells promote resistance to heterosubtypic strains of influenza via multiple mechanisms. J. Immunol. 180, 454-463.

Regnault, A., Lankar, D., Lacabanne, V., Rodriguez, A., Thery, C., Rescigno, M., Saito, T., Verbeek, S., Bonnerot, C., Ricciardi-Castagnoli, P., and Amigorena, S. (1999). Fc $\gamma$ receptormediated induction of dendritic cell maturation and major histocompatibility complex class I-restricted antigen presentation after immune complex internalization. J. Exp. Med. 189, 371-380.

Rodriguez, A., Regnault, A., Kleijmeer, M., Ricciardi-Castagnoli, P., and Amigorena, S. (1999). Selective transport of internalized antigens to the cytosol for MHC class I presentation in dendritic cells. Nat. Cell Biol. 1, 362-368.

Rossman, J. S., and Lamb, R. A. (2011). Influenza virus assembly and budding. Virology 411, 229-236.

Sambhara, S., Kurichh, A., Miranda, R., Tumpey, T., Rowe, T., Renshaw, M., Arpino, R., Tamane, A., Kandil, A., James, O., Underdown, B., Klein, M., Katz, J., and Burt, D. (2001). Heterosubtypic immunity against human influenza A viruses, including recently emerged avian $\mathrm{H} 5$ and $\mathrm{H} 9$ viruses, induced by FLUISCOM vaccine in mice requires both cytotoxic T-lymphocyte and macrophage function. Cell. Immunol. 211, 143-153.

Sandbulte, M. R., Jimenez, G. S., Boon, A. C., Smith, L. R., Treanor, J. J., and
Webby, R. J. (2007). Cross-reactive neuraminidase antibodies afford partial protection against $\mathrm{H} 5 \mathrm{~N} 1$ in mice and are present in unexposed humans. PLoS Med. 4, e59. doi:10.1371/journal.pmed.0040059

Shu, L. L., Bean, W. J., and Webster, R. G. (1993). Analysis of the evolution and variation of the human influenza A virus nucleoprotein gene from 1933 to 1990. J. Virol. 67, 2723-2729.

Skehel, J. J., and Wiley, D. C. (2000). Receptor binding and membrane fusion in virus entry: the influenza hemagglutinin. Annu. Rev. Biochem. 69, 531-569.

Skountzou, I., Koutsonanos, D. G. Kim, J. H., Powers, R., Satyabhama, L., Masseoud, F., Weldon, W. C., Martin Mdel, P., Mittler, R. S., Compans, R., and Jacob, J. (2010). Immunity to pre-1950 H1N1 influenza viruses confers cross-protection against the pandemic swine-origin 2009 A (H1N1) influenza virus. J. Immunol. 185, 1642-1649.

Smith, G. J. D., Vihaykrishna, D., Bahl, J., Lycett, S. J., Worobey, M., Pybus, O. G., Ma, S. K., Cheung, C. L., Raghwani, J., Bhatt, S., Peiris, J. S. M., Guan, Y., and Rambaut, A. (2009). Origins and evolutionary genomics of the 2009 swine-origin H1N1 influenza epidemic. Nature 459, 1122-1125.

Soboleski, M. R., Gabbard, J. D., Price, G. E., Misplon, J. A., Lo, C. Y., Perez, D. R., Ye, J., Tompkins, S. M., and Epstein, S. L. (2011). Cold-adapted influenza and recombinant adenovirus vaccines induce cross-protective immunity against pH1N1 challenge in mice. PLoS ONE 6, e21937. doi:10.1371/journal.pone.0021937

Steel, J., Lowen, A. C., Wang, T. T., Yondola, M., Gao, Q., Haye, K., GarciaSastre, A., and Palese, P. (2010). Influenza virus vaccine based on the conserved hemagglutinin stalk domain. MBio 1, e00018-e00010.

Stratov, I., Chung, A., and Kent, S. J. (2008). Robust NK cell-mediated human immunodeficiency virus (HIV)-specific antibody-dependent responses in HIV-infected subjects. J. Virol. 82, 5450-5459.

Sui, J., Hwang, W. C., Perez, S., Wei, G., Aird, D., Chen, L., Santelli, E., Stec, B., Cadwell, G., Ali, M., Wan, H., Murakami, A., Yammanuru, A., Han, T., Cox, N. J., Bankston, L. A., Donis, R. O., Liddington, R. C., and Marasco, W. A. (2009). Structural and functional bases for broadspectrum neutralization of avian and human influenza A viruses. Nat. Struct. Mol. Biol. 16, 265-273.
Sui, J., Sheehan, J., Hwang, W. C., Bankston, L. A., Burchett, S. K., Huang, C. Y., Liddington, R. C., Beigel, J. H., and Marasco, W. A. (2011). Wide prevalence of heterosubtypic broadly neutralizing human anti-influenza A antibodies. Clin. Infect. Dis. 52, 1003-1009.

Sukeno, N., Otsuki, Y., Konno, J., Yamane, N., Odagiri, T., Arikawa, J., and Ishida, N. (1979). Antinucleoprotein antibody response in influenza A infection. Tohoku J. Exp. Med. 128, 241-249.

Taubenberger, J. K., and Kash, J. C. (2010). Influenza virus evolution, host adaptation, and pandemic formation. Cell Host Microbe 7, 440-451.

Throsby, M., van den Brink, E., Jongeneelen, M., Poon, L. L., Alard, P., Cornelissen, L., Bakker, A., Cox, F., van Deventer, E., Guan, Y., Cinatl, J., ter Meulen, J., Lasters, I., Carsetti, R., Peiris, M., de Kruif, J., and Goudsmit, J. (2008). Heterosubtypic neutralizing monoclonal antibodies crossprotective against $\mathrm{H} 5 \mathrm{~N} 1$ and $\mathrm{H} 1 \mathrm{~N} 1$ recovered from human $\mathrm{IgM}+$ memory B cells. PLoS ONE 3, e3942. doi:10.1371/journal.pone.0003942

Tompkins, S. M., Zhao, Z. S., Lo, C. Y., Misplon, J. A., Liu, T., Ye, Z., Hogan, R. J., Wu, Z., Benton, K. A., Tumpey, T. M., and Epstein, S. L. (2007). Matrix protein 2 vaccination and protection against influenza viruses, including subtype H5N1. Emerging Infect. Dis. 13, 426-435.

Tosh, P. K., Jacobson, R. M., and Poland, G. A. (2010). Influenza vaccines: from surveillance through production to protection. Mayo Clin. Proc. $85,257-273$.

Treanor, J. J., Tierney, E. L., Zebedee, S. L., Lamb, R. A., and Murphy, B. R. (1990). Passively transferred monoclonal antibody to the M2 protein inhibits influenza A virus replication in mice. J. Virol. 64 1375-1377.

Tsuchiya, E., Sugawara, K., Hongo, S., Matsuzaki, Y., Muraki, Y., Li, Z. N., and Nakamura, K. (2001). Antigenic structure of the haemagglutinin of human influenza A/H2N2 virus. J. Gen. Virol. 82, 2475-2484.

Ulmer, J. B., Donnelly, J. J., Parker, S. E., Rhodes, G. H., Felgner, P. L. Dwarki, V. J., Gromkowski, S. H., Deck, R. R., DeWitt, C. M., Friedman, A., Hawe, L. A., Leander, K. R., Martinez, D., Perry, H. C., Shiver, J. W., Montgomery, D. L., and Liu, M. A. (1993). Heterologous protection against influenza by injection of DNA encoding a viral protein. Science 259, 1745-1749. 
Ulmer, J. B., Fu, T. M., Deck, R. R., Friedman, A., Guan, L., DeWitt, C., Liu, X., Wang, S., Liu, M. A., Donnelly, J. J., and Caulfield, M. J. (1998). Protective CD4+ and CD8 + T cells against influenza virus induced by vaccination with nucleoprotein DNA. J. Virol. 72, 5648-5653.

Virelizier, J. L., Allison, A. C., Oxford, J. S., and Schild, G. C. (1977). Early presence of ribonucleoprotein antigen on surface of influenza virusinfected cells. Nature 266, 52-54.

Wang, T. T., Tan, G. S., Hai, R., Pica, N., Ngai, L., Ekiert, D. C., Wilson, I. A., Garcia-Sastre, A., Moran, T. M., and Palese, P. (2010). Vaccination with a synthetic peptide from the influenza virus hemagglutinin provides protection against distinct viral subtypes. Proc. Natl. Acad. Sci. U.S.A. 107, 18979-18984.

Wei, C. J., Boyington, J. C., McTamney, P. M., Kong, W. P., Pearce, M. B., Xu, L., Andersen, H., Rao, S., Tumpey, T. M., Yang, Z. Y., and Nabel, G. J. (2010). Induction of broadly neutralizing H1N1 influenza antibodies by vaccination. Science 329, 1060-1064.

Whitley, R. J., and Monto, A. S. (2006). Seasonal and pandemic influenza preparedness: a global threat. $J$. Infect. Dis. 194(Suppl. 2), S65-S69.

Wraith, D. C., Vessey, A. E., and Askonas, B. A. (1987). Purified influenza virus nucleoprotein protects mice from lethal infection. J. Gen. Virol. 68(Pt 2), 433-440.

Wrammert, J., Koutsonanos, D., Li, G. M., Edupuganti, S., Sui, J., Morrissey, M., McCausland, M., Skountzou, I., Hornig, M., Lipkin, W. I., Mehta, A., Razavi, B., Del Rio, C., Zheng, N. Y., Lee, J. H., Huang, M., Ali, Z., Kaur, K., Andrews, S., Amara, R. R., Wang, Y., Das, S. R., O’Donnell, C. D., Yewdell, J. W., Subbarao, K., Marasco, W. A., Mulligan, M. J., Compans, R., Ahmed, R., and Wilson, P. C. (2011). Broadly crossreactive antibodies dominate the human B cell response against 2009 pandemic H1N1 influenza virus infection. J. Exp. Med. 208, 181-193.

Wrammert, J., Smith, K., Miller, J., Langley, W. A., Kokko, K., Larsen, C., Zheng, N. Y., Mays, I., Garman, L., Helms, C., James, J., Air, G. M., Capra, J. D., Ahmed, R., and Wilson, P. C. (2008). Rapid cloning of high-affinity human monoclonal antibodies against influenza virus. Nature 453, 667-671.

Xie, H., Jing, X., Li, X., Lin, Z., Plant, E., Zoueva, O., Yang, H., and Ye, Z. (2011). Immunogenicity and cross-reactivity of 2009-2010 inactivated seasonal influenza vaccine in US adults and elderly. PLoS
ONE 6, e16650. doi:10.1371/journal.pone.0016650

Xu, R., Ekiert, D. C., Krause, J. C., Hai, R., Crowe, J. E. Jr., and Wilson, I. A. (2010). Structural basis of preexisting immunity to the $2009 \mathrm{H} 1 \mathrm{~N} 1$ pandemic influenza virus. Science 328, 357-360.

Yamane, N., Odagiri, T., Arikawa, J. and Ishida, N. (1981). Reversed single-radial-immunodiffusion test: the method for the assay of the antibody to influenza A nucleoprotein. Tohoku J. Exp. Med. 133 245-255.

Yewdell, J. W., Frank, E., and Gerhard, W. (1981). Expression of influenza A virus antigens on the surface of infected P815 cells. J. Immunol. 126, 1814-1819.

Yu, X., Tsibane, T., McGraw, P. A., House, F. S., Keefer, C. J., Hicar, M. D. Tumpey, T. M., Pappas, C., Perrone, L. A., Martinez, O., Stevens, J., Wilson, I. A., Aguilar, P. V., Altschuler, E. L., Basler, C. F., and Crowe, J. E. Jr. (2008). Neutralizing antibodies derived from the $\mathrm{B}$ cells of 1918 influenza pandemic survivors. Nature 455, 532-536.

Zharikova, D., Mozdzanowska, K., Feng, J., Zhang, M., and Gerhard, W. (2005). Influenza type A virus escape mutants emerge in vivo in the presence of antibodies to the ectodomain of matrix protein 2. J. Virol. 79, 6644-6654.

Zheng, B., Zhang, Y., He, H., Marinova, E., Switzer, K., Wansley, D. Mbawuike, I., and Han, S. (2007). Rectification of age-associated deficiency in cytotoxic $\mathrm{T}$ cell response to influenza a virus by immunization with immune complexes. $J$. Immunol. 179, 6153-6159.

Conflict of Interest Statement: A patent is pending on the use of anti-NP antibodies against influenza virus.

Received: 01 August 2011; paper pending published: 12 September 2011; accepted: 26 November 2011; published online: 16 December 2011.

Citation: Kaminski DA and Lee FE-H (2011) Antibodies against conserved antigens provide opportunities for reform in influenza vaccine design. Front. Immun. 2:76. doi: 10.3389/fimmu.2011.00076

This article was submitted to Frontiers in B Cell Biology, a specialty of Frontiers in Immunology.

Copyright (c) 2011 Kaminski and Lee. This is an open-access article distributed under the terms of the Creative Commons Attribution Non Commercial License, which permits non-commercial use, distribution, and reproduction in other forums, provided the original authors and source are credited. 